\title{
Shark conservation: Analysis and synthesis
}

Ila France Porcher, Independent researcher, ilafranceporcher@protonmail.com

ORCID: \# 0000-0003-3410-4732

Researcher ID: AAX-9651-2020

Dr. Brian W. Darvell

University of Birmingham, United Kingdom

ORCID \#: 0000-0003-0291-1134

Researcher ID AAY-1497-2020

\begin{abstract}
The market for shark fin soup, a fashionable, high-end Chinese dish, has resulted in intensive shark fishing across all oceans. At the same time, $90 \%$ of teleost fish stocks are over-exploited, making sharks the most lucrative target: fisheries that have not previously hunted them are now. As top and middle predators, sharks have high ecological value and poor capacity to withstand fishing mortality, but though their numbers are plummeting, the secretive nature of the fin trade, along with the difficulties of obtaining relevant data, obscure their true status. In consumer countries, shark fin is a luxury item and rich consumers are willing to pay high prices. There is little interest in sustainability or legal trade. Thus market demand will continue to fuel the search for sharks and those accessible to fishing fleets are increasingly endangered. Current legal protections are not working, as is clearly seen in the case of the shortfin mako. Claims that sharks can withstand such targeted, industrial hunting and be sustainably fished under these circumstances are shown to be misguided. In the interests of averting a catastrophic collapse across the planet's aquatic ecosystems, sharks must be given effective protection. We recommend that all sharks, chimaeras, manta rays, devil rays, and rhino rays be protected from international trade through an immediate CITES Appendix I listing. However, a binding international agreement for protection, not only of sharks, but of the loss of biodiversity in general, is what is most needed to allow marine and fresh water ecosystems to recover.
\end{abstract}

\section{Keywords}

biodiversity conservation, sharks, shark fisheries, sustainable shark fishing, fisheries, shark fin trade 


\section{Introduction}

Shark conservation has been the subject of numerous reports over many years, with arguments for and against action to limit the fishery. In the absence of a clear conclusion or consensus, we present a detailed and comprehensive data-driven analysis of the various aspects of the matter.

The growth of the market for shark fin soup, a fashionable, high-end Chinese dish, has resulted in intensive shark fishing across all oceans, but most of the slaughter is neither recorded nor managed (Clarke et al. 2006a, b; Dulvy et al. 2008; Worm et al. 2013; Dulvy et al. 2014; Fields et al. 2017). With their low productivity, sharks have poor capacity to withstand fishing mortality (Myers \& Worm 2003) so their numbers are plummeting. In a rigorous global study in 2014, Dulvy et al. found one quarter of shark and ray species to be threatened with extinction as a result of overfishing in what could be called "a chronic accumulation of global marine extinction risk.” In 2019 the UN Biodiversity Council (IPBES 2019) warned that more than one third of all known shark and ray species are facing the risk of extinction within the next few decades and explicitly named industrial fishing as the main reason for the loss of marine biodiversity. The latest report (Pacoureau et al. 2021) found that more than three quarters of oceanic shark species are now threatened with extinction.

At the same time as the rise of the shark fin trade, some $90 \%$ of teleost fish stocks have become over-exploited (World Bank 2017), making sharks the most lucrative target. Consequently, fisheries that have not previously hunted them are now doing so (Clarke et al. 2007; Hareide et al. 2007; Dulvy et al. 2008; da Silva et al. 2021, Rosello et al. 2021). Pelagic sharks have been hardest hit (Dulvy et al. 2008; Oliver et al. 2015, Pacoureau et al. 2021) and they provide most of the fins on the market (Clarke et al. 2006a, b; Fields et al. 2017), but all accessible sharks, in a wide variety of ecosystems, are targeted.

In 2012, Nadon et al. found that reef sharks were at 3 - $10 \%$ of baseline levels on coral reefs in the Pacific Ocean. Eight years later, MacNeil et al. (2020) found that they are functionally extinct on $19 \%$ of coral reefs. The great white shark is nearing extinction in South Africa to the degree that sevengill sharks (Notorynchus cepedianus) are taking over its former hunting grounds (Hammerschlag et al. 2019). In Southeast Asia, where large numbers of shark species evolved in its diverse coral ecosystems, elasmobranchs are particularly threatened and overfished, yet no records have been kept, so the true extent of elasmobranch losses is unknown (Lam \& Sadovy de Mitcheson 2011).

In 2013 Worm et al. estimated that between 63 and 273 million sharks were killed each year, depending on whether the tonnage is made up of larger or smaller sharks. Since reports for various regions in the world indicate that most sharks caught are immature (Ward \& Myers 2005, Lam \& Sadovy de Mitcheson 2011, Doherty et al. 2014, ICCAT 2019), it is likely that the true number was closer to the higher estimate. Currently, about 600,000 metric tonnes (t) of sharks and rays are caught each year by just the world's top 20 shark fishing nations (Okes \& Sant 2019). These figures do not account for bycatch, dead discards, illegal or unrecorded catches, or the high post-release mortality resulting from poor handling procedures (Hutchison et al. 2015) in the case of threatened species on which there is a retention ban.

Jurisdictional issues, along with the difficulties of obtaining relevant data, have long obscured understanding of sharks' diversity and true numbers (Stevens et al. 2000). They range far from land and migrate across oceans, outside countries’ Exclusive Economic Zones (EEZs), so their status is 
difficult for Regional Fisheries Management Organizations (RFMOs) to assess. IUCN (2019) listed 198 data-deficient shark species out of the 494 assessed. RFMOs have placed higher priority on species with greater economic importance, so shark management in general has been low priority, poor, or entirely lacking (Stevens et al. 2000; Dulvy et al. 2008; Davidson et al. 2016; Cashion et al. 2019).

In consumer countries, shark fin is a luxury item and there is little interest in sustainability or legal trade. Rich consumers are willing to pay high prices while the will, oversight, and enforcement resources necessary to manage the trade are absent. Thus market demand will continue to fuel the intensive search for more sharks, and the problem is likely to become greater as scarcity forces prices up (Sadovy de Mitcheson et al. 2018). In 2016, Campana estimated the shark fin market to be worth approximately US\$350 million annually.

Although the idea that sharks are being fished sustainably around the world is still put forward (Simpfendorfer \& Dulvy 2017; Shiffman \& Hueter 2017; Shiffman et al. 2021), in 2020 Ferretti et al. found that $91.3 \%$ of shark catches are biologically unsustainable and that globally only 16 shark fisheries were well managed (Feretti et al. 2020). But even in well-managed shark fisheries, ecosystem impacts are difficult to detect and evaluate, so they are ignored in stock assessments (Ferretti et al. 2010; Travis et al. 2014). Most shark species are impossible to catch selectively (Walker 1998), especially when using longline gear, so other shark species will be caught as bycatch, including those that are overfished or threatened (Campana 2016, Pacoureau et al. 2021).

Increasing numbers of shark and ray species are found to be critically endangered or endangered and given the nature of the shark fin trade, without intervention the situation will continue to decline. In the interests of averting a catastrophic collapse across the planet's diverse marine, riverine and estuarine ecosystems, sharks and their habitats must be given effective protection (IPBES 2019, Pacoureau et al. 2021).

\section{The impact of industrial fishing}

With approximately 2.9 million motorized fishing vessels hunting the global ocean, the footprint of industrial fishing exceeds other forms of food production (Kroodsma et al. 2018). Modern longliners, sea bottom and deep sea trawling, and drifting fish aggregating devices (dFADs) are particularly lethal (Jones 1992; Sumaila et al. 2010; Norse et al. 2011; Filmalter et al. 2013; Hanich et al. 2019). However, wild fisheries provide only $1.2 \%$ of global caloric production for human food consumption (Kroodsma et al. 2018).

Industrial fishing began throughout the world's tropical and temperate oceans after WWII, although some areas were being fished intensively prior to that (Myers \& Worm 2003; Ward \& Myers 2005; Ferretti et al. 2010). Fishing pressure has escalated (Kroogsma et al. 2018) an estimated 18-fold since 1970 (Pacoureau et al. 2021).

By 2003, the global ocean had lost an estimated $90 \%$ of its predators, $80 \%$ within the first 15 years of industrial exploitation (Myers \& Worm 2003; Ward \& Myers 2005). This suggests that by 1970, the baseline used by Pacoureau et al. (2021) for their calculations of shark depletion, sharks were already severely depleted. Since then, the abundance of oceanic sharks has decreased by some $71 \%$, while tropical sharks have declined by an average of $87 \%$ despite their more resilient life history (Pacoureau et al. 2021). This means that overall only about 6\% remain of the numbers present in 1950 , and only about $3 \%$ in the case of tropical sharks. 
Sharks were always a substantial bycatch taken by longliners, drift nets, purse seine nets and bottom trawlers. In the Atlantic Ocean, longliners caught two or three sharks for every swordfish, and in the Gulf of Mexico and Pacific Ocean one shark was caught for every two yellowfin tuna (Ferretti et al. 2010). They were mostly discarded as trash while official fisheries statistics recorded only landed catches (Campana 2016; Fordham et al. 2016).

Industrial fishing resulted in rapid and extreme declines in shark catches (Myers \& Worm 2003; Ward \& Myers 2005). In the Pacific, for example, the catch of silky shark (Carcharhinus falciformis) decreased by some 92\%, while in the Gulf of Mexico catches of the oceanic whitetip (Carcharhinus longimanus) fell by more than 99\% (Ferretti et al. 2010). Along the eastern shore of the United States of America (USA) huge declines were recorded: 87\% for sandbar sharks (Carcharhinus plumbeus), 93\% for the oceanic blacktip (Carcharhinus limbatus), 97\% for tiger sharks (Galeocerdo cuvier), 98\% for scalloped hammerheads (Sphyrna lewini), and more than 99\% for bull (Carcharhinus leucas), dusky (Carcharhinus obscurus) and smooth hammerhead (Sphyrna zygaena) sharks (Myers et al. 2007). Ecologically, they were functionally removed (Heithaus et al. 2008).

Over-exploitation and collapse of the porbeagle (Lamna nasus) population in the Northeast Atlantic in the 1960s led to intensive directed fishing in the Northwest Atlantic, where most of the virgin biomass was removed in just six years (Dulvy et al. 2008). A similar situation is now ongoing for the spiny dogfish (Squalus acanthias) (Fordham et al. 2016).

In the South China Sea, 109 species of sharks were recorded as being fished in the 1970s but only 18 are present in current market surveys. The market is now dominated by smaller species, of which $65 \%$ are under the age of sexual maturity (Lam \& Sadovy de Mitcheson 2011). Indonesia is the largest shark fishing country in the world and its annual catch exceeds 100,000 t per year from its 17,000 islands (Sadovy de Mitcheson et al. 2018), yet fishery management is virtually absent. Japan has operated some of the largest elasmobranch fisheries in the Northwest Pacific and was already trading shark fins with China more than 200 years ago. Japan's large trawl fisheries showed signs of being over-exploited before World War II, so in the Northwest Pacific shark exploitation may have peaked before the 1950s (Ferretti et al. 2010). In the Mediterranean, trawl fishing led to the loss of 16 out of 31 species in the Tyrrhenian Sea, 6 out of 33 species in the Adriatic Sea, and half of the species in the Gulf of Lion since the 1950s. Nine of the 16 shark species still landed in the Mediterranean are more threatened regionally than at the global level and between 53 and $71 \%$ are at risk of extinction (Cashion et al. 2019). Pelagic fisheries landings in Brazil recorded the disappearance of 14 species of carcharhinids between 1977 and 1994 (Amorim et al. 1998). Devil ray abundance has declined by at least $85 \%$ in just the past 15 years in the Southwest Indian Ocean (Pacoureau et al. 2021).

Since the 1980s, the tuna industry has increasingly made use of dFADs, and half of all tuna are now caught using them (Balderson \& Martin 2015). These consist of floating platforms trailing lengths of netting to ensure that they move with the ocean currents, rather than being swept along by the wind. They maximize their catch by taking advantage of the tendency of tuna to shelter beneath floating objects. However, a variety of other marine animals, including the juveniles of oceanic whitetip and silky sharks, also use that shelter, and are therefore a major bycatch in those fisheries. Drifting FADs are left to drift, usually for several months between visits by the fishing fleet, which then uses purse seines to net the entire shoal of fish that has accumulated beneath them. In the Indian Ocean over $80 \%$ of the purse seine catch is now made using dFADs (Hanich et al. 2019), 
and between 480,000 and 960,000 silky sharks, most of which are juveniles, are killed each year through entanglement in those trailing nets (Filmalter et al. 2013). This mortality, from the Indian Ocean alone, is comparable in scale to the entire reported world fishing catch of 400,000 to 2,000,000 animals, the silky shark being second only to the blue shark for use in the fin trade (Fields et al. 2017). Although some RFMOs are beginning to demand that dFADs must be nonentangling, the criteria for a non-entangling $\mathrm{dFAD}$ are still very weak. Many dFADs constructed to be non-entangling become entangling with the passage of time (Wang et al. 2020).

\section{The ecological consequences}

In pristine, unfished regions, sharks are abundant and diverse (Ferretti et al. 2010). As highly successful top and middle predators, they survived the several mass, global extinctions and, through radial evolution, adapted to new ecological niches (Kriwet \& Benton 2004; Kriwet et al. 2009; Guinot \& Calvin 2016). Thus, over the past 500 million years, they became deeply woven into the aquatic ecosystems of the planet. But industrial fishing resulted in a large-scale ecological transformation, not only in terms of the size of individuals and the relative abundance of species, but also community biomass (Stevens et al. 2000; Ward \& Myers 2005; Myers et al. 2007; Ferretti et al. 2010; Travis et al. 2014). The removal of top predators causes alternating increases and declines in the abundance of lower levels on the food chain, an effect called a 'trophic cascade' (Ward \& Myers 2005). However, due to the difficulties in studying marine ecosystems, particularly in deep waters, few such cases have been identified and little is known about the complex ecological roles played by sharks (Stevens et al. 2000; Mumby et al. 2006; Myers et al. 2007; Heithaus et al. 2008, Pacoureau et al. 2021).

Food-web models suggest that large sharks are among the most strongly interacting species (Freire et al. 2008), and that their overfishing may have contributed to the degradation of the coral ecosystems in the Caribbean (Bascompte et al. 2005). A 'removal' computer simulation conducted for the reef ecosystem of Floreana Island in the Galápagos Islands found that sharks were at the top of the trophic scale and that their loss caused a four-level trophic cascade (Okey et al. 2004). Toothed cetaceans, sea lions, marine iguanas, and other mid-level predators were predicted to increase, which led directly to intensified predation on reef fish and a decline in their numbers. This in turn led to an increase in small benthic invertebrates. Other trophic cascades were also apparent. The removal of the sharks caused a rebalancing of the entire ecosystem.

The presence of large sharks has a marked effect on the behaviour of prey species. The removal of tiger sharks so affected the evasion behaviour of dugongs and green sea turtles in Shark Bay, Australia, that the sea floor patterns of sea grass and its nutrient composition were significantly changed (Heithaus et al. 2007, 2008). The removal of the great sharks is likely to have allowed multitudes of smaller species to move into the sunlit upper layers of the ocean during the daylight hours, whereas formerly they only migrated upwards at night (Ward \& Myers 2005).

Some elasmobranchs, including reef and tiger sharks, leave their ranges for a period of weeks when fishing begins (Porcher 2010, 2017), putting their communities into disarray (Mourier et al. 2012, Papastamatiou et al. 2020). The tendency to flee when some of their number are killed was independently seen in reef sharks in French Polynesia and tiger sharks in the Bahamas, suggesting that it is a widespread reaction to fishing pressure.

The depletion of top predators, therefore, causes deep disruption in ecological communities that is 
widespread and long-lived (Heithaus et al. 2008; Ferretti et al. 2010). Over more than seven decades, industrial shark removal has resulted in major shifts in biomass and size composition in all oceans (Ward \& Myers 2005; Myers et al. 2007; Ferretti et al. 2010). The mean weight of blue sharks (Prionace glauca) caught was $52 \mathrm{~kg}$ in the 1950s, but just $22 \mathrm{~kg}$ in the 1990s, while the species abundance fell to only 13\% of that of the 1950s (Ward \& Myers 2005). Along the Eastern coast of the USA, 11 species of large shark declined between 1970 and 2005, while catch rates for 14 small elasmobranch species increased from about 1\% to some 26\% per year (Myers et al. 2007; Heithaus et al. 2008). Ten-fold declines in 12 large pelagic predators between 1950 and 2000 were noted in the Pacific Ocean at the same time that pelagic stingrays (Dasyatis violacea) and other smaller elasmobranchs increased some 10- to 100-fold (Heithaus et al. 2008). In the North Sea, a rich ecosystem of elasmobranchs was changed to one consisting of a few small, productive species such as small spotted cat sharks (Scyliorhinus canicula) and small skates (Ferretti et al. 2010). However, RFMOs do not take the ecological consequences of shark removal into account (Travis et al. 2014).

\section{A barrier to shark conservation}

Following the release of the movie JAWS in June 1975, a wave of hatred for sharks swept the public, and, particularly in the USA, recreational fishermen went out to kill the perceived monsters en masse (Drumm 1996). In the decades since, nature horror shows presenting sharks as dangerous man-eaters have continued to fuel the slaughter and raised a barrier against shark conservation. Until recently, conservation was considered to be an unpopular subject for television audiences so the extreme depletion of sharks by recreational and industrial fisheries received little publicity.

Further, shark science has been influenced by fisheries and the effort to develop 'shark attack' repellents (Castro 2017). Historically, researchers have studied sharks through dissection or tagging, which distances them from the animal, so that they do not see its behaviour. Researchers have been further misled by the prevailing idea that evolution produced a hierarchical or pyramidal structure of life forms, with humans on the top, making the elasmobranchs, that separated from our phylogenetic line 440,000,000 years ago, among the lowest and very coldest of animals.

As a result of these factors, there is a strong public bias against sharks. They have not been included in welfare considerations as have other fish, reptiles, birds and mammals (Broom 2014), though they, too, are known to be capable of cognition and are likely conscious (Schluessel 2015).

However, although public concern about them has grown in recent years (Friedrich 2014), with many organizations and individuals promoting activity (e.g. PADI 2011), they have still not been granted effective protection.

\section{The uncertainties}

In 2015, the International Scientific Committee for Tuna and Tuna-like Species in the North Pacific Ocean (ISC) analysed shortfin mako (Isurus oxyrinchus) stocks using the most complete data available. It found that due to missing information, untested indicators, and conflicts in the available data, an assessment was impossible to make (NOAA 2016).

Besides the difficulties in assessing the status of sharks due to their deep water habitats and vast ranges, most mortality is not recorded. Clarke et al. (2006a b) studied the shark fin market in Hong 
Kong between 1999 and 2001, and at that time the shark mortality necessary to support the shark fin trade was four times what had been reported to the Food and Agriculture Organization of the United Nations (FAO) (the only organization that keeps global fishing records). They found that about 1.7 million tonnes of sharks were being sacrificed for the vanity soup each year, but cautioned that these estimates were low and did not include shark mortality that did not produce fins (such as hooking mortality, post-release mortality, predatorial mortality during longlining, and the killing of sharks by fishermen to reduce bait loss on future sets, as well as incidental, artisanal, and recreational catches and discards). Estimates based on recorded catches, therefore, underestimate the mortality that sharks are actually facing by about four times, and possibly much more.

Global studies have emphasized the problems inherent in assessing the status of sharks, providing detailed descriptions of the difficulties on every level (Clarke et al. 2006a, b; Worm et al. 2013; Dulvy et al. 2014; Dent \& Clarke 2015; da Silva et al. 2021). For a shark fishery to be sustainable, it must be possible to determine not only what the shark fishing mortality is, but also the mortality that will produce maximum sustainable yield (MSY), yet in the case of sharks those reference points are often not known or are extremely uncertain (Worm et al. 2013; Dulvy et al. 2014; Campana 2016; ICCAT 2019; Queiroz et al. 2019). Most shark hunting nations still do not keep species-specific catch records (Clarke et al. 2006a, b; Musick \& Musick 2011; Dent \& Clarke 2015; Fields et al. 2017), and recorded catches from industrial fisheries are known to be inaccurate. Catch data from artisanal fisheries are generally ignored, but in many regions they are significant (IOTC 2020). In the Indian Ocean, for example, such fisheries are not required to report shark catch data, contributing to the underestimation of shark mortality (IOTC 2020). These uncertainties are amplified by the vagueness and secrecy involved in the trade in shark products (Dent \& Clarke 2015).

\subsection{Illegal, unreported, and unregulated fishing}

Illegal, unreported, and unregulated (IUU) fishing takes about $20 \%$ of the world's fishing catch, and as much as $50 \%$ in some fisheries. It is valued at between $\$ 10$ billion and $\$ 23.5$ billion annually from 11 to 26 million tonnes of fish (Agnew et al. 2009). These losses contribute to the unreliability of stock assessments, and to the danger of their collapse (Widjaja et al. 2020). As top-valued animals, sharks are especially vulnerable: in all four tuna RFMOs, fishing vessels regularly retain valuable shark species, including oceanic whitetip, scalloped hammerhead, and silky sharks, in spite of retention bans (IOTC 2020).

IUU fishing includes fishing which directly contravenes laws, fishing conducted under the area of management of a RFMO in a manner that contravenes the conservation and management rules of that organization, and fishing done outside of management areas in a manner that is not consistent with state responsibilities for the conservation of marine resources under international laws (Widjaja et al. 2020). It is correlated with poor governance, resulting in a lack of management of fishing capacity and consequent overfishing (Meere \& Lack 2008). With seafood in high demand, and the difficulties inherent in enforcing fisheries management, particularly on the high seas, IUU fishing is profitable. Globally, there has been a lack of political will to take the actions required to address it (Meere \& Lack 2008).

The United Nations Convention on the Law of the Sea (UNCLOS), the FAO Code of Conduct for Responsible Fisheries (CCRF), and the UN Fish Stocks Agreement (UNFSA), as well as a variety 
of other international codes of conduct, agreements and regulations, have been put in place for the purpose of ensuring that fishing activities are conducted responsibly. Their objectives include taking the precautionary approach to fisheries management, ensuring that bycatch and waste are minimized, that the marine environment is conserved to sustainable levels, and that the economic interests of coastal communities are taken into account. RFMOs, as well as the large seafood companies, are those in a position to ensure that these principles are respected (Greenpeace 2020). But, compliance with these measures is poor. Many vessels intentionally violate laws on the virtually unmonitored high seas (Meere \& Lack 2008). Without a strong, internationally binding High Seas Treaty there is almost no prosecution to be feared by fishing fleets for violations, even if detected.

For example, Taiwan has over 1,100 flagged vessels fishing across all the oceans, and hundreds more Taiwanese-owned vessels are flagged to other countries. It is one of the world's largest distant-water fishing powers. It is a party to several RFMOs, including the Inter-American Tropical Tuna Commission (IATTC), the International Commission for the Conservation of Atlantic Tunas (ICCAT), the Indian Ocean Tuna Commission (IOTC), and the Western and Central Pacific Fisheries Commission (WCPFC). Yet Greenpeace (2020) found that 50\% of its ships practised shark finning. Thirteen percent killed toothed cetaceans, such as dolphins and false killer whales, to use as shark bait or to sell. (The meat of dolphins is extremely attractive to sharks and stays on the hook better than fish meat.) Further, 92\% of ships in the Taiwanese fleet committed human rights abuses. These included the withholding of wages, excessive overtime (20 h/day shifts), deception, physical violence, and passport confiscation with no recourse to apply for justice. In spite of some improvements and efforts to legalize the Taiwanese fleet, continued violations are reported.

Taiwan is home to one of the top three tuna traders in the world, Fong Chun Formosa Fishery Company, Ltd., which recently purchased the American canned tuna company 'Bumble Bee', making it a major supplier of tuna to consumers in the USA (Greenpeace 2020). It is a telling illustration of how successful and insidious is IUU fishing in today's market.

In all four tuna RFMOs, fishing vessels regularly retain valuable shark species, including oceanic whitetip, scalloped hammerhead, and silky sharks, in spite of retention bans (IOTC 2020).

\subsection{Other markets}

As well as the shark fin market, the increasing demand for a component of shark liver oil, squalene, is a prominent cause of shark mortality. Squalene fishermen often extract the animal's liver and throw the body back into the ocean, which is called "shark livering." The scale of the shark liver oil market requires more than three million deep-sea sharks annually and targets species with large livers such as the Greenland shark (Somniosus microcephalus), the whale shark (Rhincodon typus), and deep-sea sharks including the gulper shark (Centrophorus granulosus), the leafscale gulper shark (Centrophorus squamosus) and the Portugese dogfish (Centroscymnus coelolepis). Even when they are caught in low numbers, deep-sea sharks are extremely vulnerable to fishing.

However, except in South Korea, there is no standard code designating shark liver oil or squalene, and countries do not declare their catches to the FAO. It is therefore impossible to analyse the global market in any detail (Chabrol 2012). Yet, shark meat and oil are now being used in everything from make-up to dogfood, particularly from blue, shortfin mako and scalloped hammerhead (Sphyrna lewini) sharks (Cardeñosa 2019). Given the success of IUU fishing, 
threatened species easily find their way into the market.

\subsection{Replacing depleted species}

The high diversity of shark species in the Hong Kong shark fin market indicates the likelihood that species more sensitive to fishing pressure are being replaced by others as their numbers become depleted. Such substitution could mask losses of declining species (Fields et al. 2017).

When landings of species complexes appear to remain stable, or even increase, in spite of intensive fishing, the declines or disappearance of the more sensitive members can go unnoticed while removal continues because overall yields are sustained by the more productive species in an unperceived target replacement (Davidson et al. 2016). Continued fishing pressure on such populations has often resulted in their total collapse (Stevens et al. 2000; Ferretti et al. 2010). Species replacement contributes to the uncertainties inherent in shark fisheries data (Ferretti et al. 2010).

Examples include the disappearance of three of the largest skate species from British waters, and steep declines in others, all while fishery reports on "skates and rays" claimed that the populations were stable (Davidson et al. 2016).

The angel shark (Squatina squatina) was nearly fished to extinction in Europe. It was recorded and sold under the name "monkfish", but as the catch dwindled, fishermen substituted anglerfish (Lophius spp.) which was then sold under the same name (Davidson et al. 2016).

Similarly, as many popular fish species have become critically depleted and scarce, sharks have been substituted, using a false label to sell them.

In the USA, The New York Times Magazine reported that

"stocks of dogfish were nearly wiped out not once but twice, though only after the fish became known first as rock salmon and later as Cape shark.” (Hesser 2006)

In 2019 Hobbs et al. used DNA Barcoding to identify species sold in the UK. Out of 79 tested samples of "fish and chips" sold as takeaways, 71 were spiny dogfish-almost $90 \%$. They were labelled as 'Rock Eel', 'Rock Salmon', 'Rock', or 'Huss', thereby making it almost impossible for consumers to know that they were eating shark meat, and possibly the meat of a threatened species. Indeed, in Britain, various species of dogfish have been sold under such names as well as 'flake' and 'rockfish' [OED Online, 2021], presumably to disguise what might otherwise be seen as unpalatable. The spiny dogfish is critically endangered in the Eastern North Atlantic (Hobbs et al. 2019); these authors found that cheap fast-food outlets were the best places to disguise shark meat and sell it under a false name.

In Brazil, where shark meat is considered to be low quality, it is sold under the name 'cação', for better consumer acceptance, as well as without labelling and at lower prices (da Silva et al. 2021).

In Australia 'flake' is the name used for the meat of a wide variety of sharks, including the endangered school shark (Galeorhinus galeus), the endangered scalloped hammerhead, and the critically endangered whitefin swellshark (Cephaloscyllium albipinnum). According to the Australian Marine Conservation Society (AMCS), 'flake' is widely used for fish and chips (AMCS), but less than 30\% of fish and chips shops label the species being used correctly (Guida 2021). In their report, AMCS highlighted the fact that the most popular seafood in Australia exploits 
these endangered sharks, yet half of the consumers are not aware that they are eating shark when they buy 'flake' (Guida 2021).

\section{Shark conservation measures}

The regulations intended to protect and manage sharks in recent decades have been ineffective in stopping the decline in their numbers (Ward-Paige et al. 2012; Davidson et al. 2016; Pacoureau et al. 2021). Listings by the Convention on International Trade in Endangered Species of Wild Fauna and Flora (CITES) are proving inadequate in the face of the secretive shark fin trade (Fields et al. 2017; Cardeñosa et al. 2019; Booth et al. 2020). Protection can only be gained one species at a time, while the shark fin market is indiscriminate, taking fins from essentially any species of shark or ray. Once separated from the animal, it is time consuming to determine from which species a fin has been taken, so enforcement is weak (Clarke et al. 2006a). Further, listings are opposed by shark hunting nations because of the high commercial value of the fins (Worm et al. 2013). To date, only 5 species of ray (sawfish) and not one species of shark has been listed under CITES’ Appendix I in spite of their ongoing depletion and the acknowledged threat of extinction, though 14 species of shark and 27 species of ray, including the IUCN critically-endangered rhino rays, have been included under Appendix II.

However, an Appendix II CITES listing only requires a "Non-detrimental" finding to export fins from the listed species - it grants no protection from being fished in the first place. Since fins can be stockpiled until a "Non-detrimental" finding can be arranged, the loophole undermines the protection that was intended by the original CITES listing (CREMA 2018). Further, shark hunting nations avoid granting protection to endangered sharks by claiming that they are not wildlife but species of commercial interest to fisheries (pers. comm. Arauz 2021; Shiffman et al. 2021).

The whale shark, for example, continues to decline in both abundance and size in spite of being protected by the Convention on the Conservation of Migratory Species of Wild Animals 2010 (CMS) - the 'Bonn Convention', CITES, and the Commonwealth Environment Protection and Biodiversity Conservation Act (EPBC) (Ward-Paige et al. 2012). In 1999 it was listed on Appendix II of the CMS and on Appendix I in 2017 (CMS 2020). Similarly, the sand tiger shark (Carcharias taurus) in southern Australia has been protected from fishing since 1984, but due to the high rate of incidental hooking the population continues to decline (Ward-Paige et al. 2012).

In 2015, 52\% of fins (by weight) analysed in the Hong Kong market were CITES-listed sharks (Cardeñosa et al. 2019). In a later study, fins from 76 species of elasmobranchs were found being traded in Hong Kong, one third of which were considered to be threatened with extinction (Fields et al. 2017). In 2017, a shipment of shark fins intercepted in Germany, en route from Mexico to Hong Kong, was found to include four species of CITES-listed sharks out of eleven (Villate-Moreno et al. 2021).

It is clear that an Appendix II listing for sharks is not sufficient to protect them.

\subsection{Finning bans and Fins Naturally Attached policies}

Finning bans were thought to be a viable means to combat shark finning in the belief that they would result in a decline in shark mortality (Clarke et al. 2007, 2013). A fins-to-carcass ratio of 5\% has generally been adopted (calculated as fins being $5 \%$ of the weight of the sharks on board the 
fishing vessel). This was intended to indicate that no sharks had been finned and discarded at sea. However, these ratios are almost impossible to verify, especially when fins have been dried or are frozen, and the legislation has not helped to improve data availability with respect to the true numbers and species of sharks being caught.

As a result, several jurisdictions introduced a 'fins naturally attached' (FNA) regulation that requires that fins cannot be cut off at sea but must be landed naturally attached to the carcass. This is now considered to be the only way to guarantee that finning did not occur (Cortés et al. 2006), and to permit the true numbers, species, and size of the sharks caught to be reported accurately for the analysis of fishing-induced mortality.

The FNA policy has been an important improvement and is globally acknowledged as being the best practice (Cortés et al. 2006; Fischer et al. 2012, Biery et al. 2012). It has been implemented in many countries and RFMOs including Costa Rica (2008), USA (2011), EU (2013), India (India 2013), Canada (2019), North East Atlantic Fisheries Commission (NEAFC) (2015), Northwest Atlantic Fisheries Organization (NAFO) (2017), and General Fisheries Commission for the Mediterranean (GFCM) (2018).

However, there is no strict FNA policy for vast regions of the high seas, including the Indian Ocean (IOTC), the Western Central Pacific (WCPFC), the Atlantic Ocean and adjacent seas (ICCAT), and the Eastern Pacific Ocean (IATTC). These authorities continue to allow the $5 \%$ rule, or other finsto-carcass ratios, as sufficient proof that finning does not occur, so for most of the High Seas finning bans remain the only form of control on shark catches.

For the industry, fins-to-carcass ratios are easier to implement than an FNA policy or catch reductions, so many fisheries still strongly oppose their adoption. In spite of the very high rate of elasmobranch mortality, RFMOs have perceived the monitoring, assessment, and enforcement capacity required to manage shark fisheries as being prohibitively costly (Worm et al. 2013).

\subsection{Shark sanctuaries and fishing bans}

The idea that the maximum sustainable yield should be taken for every possible species is by no means universal, even in maritime nations. French Polynesia, for example, wanted its sharks neither fished nor disturbed, and when companies from Asia began intensive shark removal throughout the vast archipelago of that island nation, the government responded by turning its entire EEZ, which is the size of Europe, into a shark sanctuary (Porcher 2010; Ward-Paige 2017). In the following years, this resulted in the complete recovery of the severely depleted populations of sharks. Other nations too, have become shark sanctuaries in response to the shark fin trade (Ward-Paige 2017; Animal Welfare Institute 2019) as shown in Table 1.

Unfortunately, these sanctuaries are still limited to a few nations that have understood that the lifetime value of sharks is substantially better for their economies than the one-time revenues from shark fishing and the shark fin trade. But enforcement is often poor due to a lack of sufficient surveillance and monitoring at sea and in the ports, while the prosecution and conviction of offenders are difficult. 


\begin{tabular}{|c|c|c|}
\hline Year & Nation & Comments \\
\hline 1980 & Israel & No shark fishing (sharks are not kosher) \\
\hline 2001 & Congo-Brazzaville & No shark fishing \\
\hline 2004 & Ecuador & $\begin{array}{l}\text { Only enforced around Galapagos; sharks caught elsewhere can be } \\
\text { landed in Ecuador }\end{array}$ \\
\hline 2006 & French Polynesia & No shark fishing \\
\hline 2006 & Egypt & No shark fishing up to $12 \mathrm{NM}$ from shore but only in the Red Sea \\
\hline 2008 & Kuwait & Some species are exempt \\
\hline 2009 & Palau & EEZ is a shark sanctuary with no shark fishing \\
\hline 2010 & Maldives & No fishing for rays and skates in EEZ since 2014. \\
\hline 2011 & Tokelau & \\
\hline 2011 & Marshall Islands & $\begin{array}{l}\text { No commercial shark fishing; no retention of shark bycatch; ban } \\
\text { on shark trade }\end{array}$ \\
\hline 2011 & Bahamas & No commercial shark fishing; ban on trade of all shark products \\
\hline 2011 & Honduras & No shark fishing \\
\hline 2012 & Cook Islands & \\
\hline 2013 & Brunei & In EEZ; ban on trade of shark products \\
\hline 2013 & $\begin{array}{l}\text { New Caledonia } \\
\text { (French) }\end{array}$ & In EEZ \\
\hline 2014 & United Arab Emirates & $\begin{array}{l}\text { Temporary shark fishing ban in place; no export of any shark } \\
\text { products }\end{array}$ \\
\hline 2015 & $\begin{array}{l}\text { Federated States of } \\
\text { Micronesia }\end{array}$ & Sharks protected in EEZ \\
\hline 2015 & Cayman Islands (UK) & In EEZ \\
\hline 2015 & Kiribati & In EEZ; ban on trade of shark products \\
\hline 2015 & Bonaire & Sharks protected in marine sanctuary around islands \\
\hline 2015 & Sabah & Sharks protected in marine sanctuary around islands \\
\hline 2015 & British Virgin Islands & No commercial shark fishing \\
\hline 2015 & Madagascar & \\
\hline 2015 & Turks and Caicos & Ban on export of sharks \\
\hline 2016 & St Maarten & In EEZ \\
\hline 2017 & Dominican Republic & \\
\hline 2018 & American Samoa & No shark fishing within $3 \mathrm{NM}$ of coast \\
\hline
\end{tabular}

Table 1: Nations that have banned shark fishing.

In some cases, the laws are not strong enough to provide complete protection for sharks. In Egypt for example, shark fishing is only banned in part of the country, while others, including the Maldives, have not imposed strong enough measures to prohibit the retention of sharks caught as bycatch in other fisheries. In addition to a ban on shark fishing, the Bahamas enforces a trade ban on shark products, but other nations have not done so. National bans cannot be considered to be a guarantee of safety for sharks since they can be lifted again.

To date, no major shark fishing nation has taken effective steps to protect its sharks from being fished, with the exception of a few attempts to define Marine Protected Areas (MPAs). However, these are often too small to provide the required degree of protection. Fishing for pelagic sharks is often still allowed, as, for example, in most of the MPAs in the Azores. 


\subsection{The Fisheries Certification Standard for sustainable seafood}

The Marine Stewardship Council (MSC), which awards its label to presumed sustainable fisheries, admits that finning still occurs in certified fisheries in spite of having been banned since 2012. Its Fisheries Certification Standard accepts the fins-to-carcass ratio with some degree of external validation as sufficient proof that finning is unlikely to have occurred. Conformity Assessment Bodies (CABs), which perform the assessment and certification of fisheries, are advised by MSC to consider only systematic finning or successful convictions as evidence for non-compliance with MSC’s proclaimed zero-tolerance policy on finning (Arauz 2018; Ziegler 2019; Ziegler et al. 2021). No fishery has ever been deemed non-eligible for certification. The MSC has therefore been widely criticized, both by environmental organizations and civil society, for its failure to require that an FNA policy is in place as a prerequisite for certification.

The level of monitoring and surveillance that is accepted by certification agents is also insufficient. An observer level of only $5 \%$ is often considered a sufficient degree of external validation to prove that finning is not taking place in a fishery. Environmental organizations, retailers, and even other fisheries, have therefore requested that both an FNA policy and a risk-based level of monitoring and surveillance of compliance must be introduced as essential (Ziegler 2019; Ziegler et al. 2021). (Risk-based monitoring requires that there be a greater level of surveillance and better external validation of compliance for those fisheries that have a higher risk of shark finning, while for lowerrisk fisheries the burden of demonstrating compliance is reduced (Ziegler et al. 2021)).

\section{The shark meat problem}

The use of finning bans and FNA policies have diverted attention from the central problem: the unsustainability of shark catches. Instead of reducing mortality, the resulting trend has been towards less detaching of the fins (Clarke et al. 2013), while a surplus of low-value shark meat has been forced onto markets around the world (Clarke et al. 2007; Dent \& Clarke 2015; da Silva et al. 2021). Although only the fins are valuable, the whole shark has to be used. Thus, to a large extent, the shark fin market drives the market for shark meat.

In Costa Rica and other South and Central American countries, for example, sharks were considered undesirable and not used for food prior to the 1980s. Then the inflated price of shark fins resulted in sharks of many species, from a wide variety of habitats, being targeted for their fins alone. The subsequent FNA policies obligated fishermen to land fins attached to the bodies, and the shark fin industry put the surplus meat on the market for domestic consumption. Merchants pushed the meat onto local consumers, relying on the use of various other names to sell it. Now, Costa Ricans alone are consuming about 2000 tons of shark meat a year, and the situation is similar in many other countries (Porcher et al. 2019).

In the USA, fishermen are applying powerful political pressure to be allowed to continue to fish sharks and profit from the shark fin trade, in spite of the global danger to sharks, even attempting to scare Americans with the threat of more shark attacks if they cannot kill the animals (Gehan 2019). When Texas passed a law requiring that all dead sharks shipped through the state must have their fins naturally attached, meaning that fishermen could no longer sell the fins, the Western Gulf of Mexico shark fishery was effectively shut down in 2019 (Gehan 2019), a telling illustration of how the shark fin market drives shark fisheries.

However, sharks are long-lived top and middle predators and their meat has high levels of 
accumulated toxins. For example, the Florida Fish and Wildlife Conservation Commission's (FWC) (2020) fishing rules specify a minimum size of 54 inches for about half of the shark species caught. At the same time, the Florida Advisory on Fish Consumption (2019) advises that no species of coastal shark longer than 43 inches should ever be eaten by anyone due to its high mercury content. Thus fishermen are specifically advised to catch large sharks, which are the breeding femalesmature female sharks of the species targeted are significantly larger than the males-yet at the same time they are considered too toxic to eat.

In parallel, the spiny dogfish fishery in the Northwest Atlantic is being expanded in spite of the finding that 32\% of spiny dogfish exceed the United States Environmental Protection Agency (US EPA) recommended threshold level of 0.3 ppm of mercury (US EPA, 2000), and concerns that the meat could have an adverse effect on consumers (Taylor et al. 2014). The Maine Seafood Guide (2020) warns that dogfish meat

"may contain amounts of mercury in excess of the recommendation of the USA Food and Drug Administration’s (FDA) recommended limit”.

It advises that

"pregnant and nursing women, women who may get pregnant, and children under 8 years of age"

should not eat any shark, and others should eat no more than two such meals a month. Shark fins, especially the commonly traded species, are also found to contain high levels of toxins, including mercury and arsenic (Barcia et al. 2020).

Shark fisheries are therefore targeting an animal that is both a potential risk to human health and globally threatened.

\section{Sustainability in shark fisheries}

The global markets for shark meat and fins have been separate in the past, and relied on different species (Dent \& Clarke 2015). Those considered sustainable are those few in the USA, New Zealand, Australia, and Canada that have fished sharks and skates for meat (Simpfendorfer \& Dulvy 2017). However, since these fisheries are now being propped up economically by the value of the sharks' fins (Shiffman \& Hueter 2017, Wiersma \& Carroll 2018) their long-term viability is questionable (Porcher et al. 2019).

\subsection{The spiny dogfish}

In the USA, the fishery for spiny dogfish is one of those advertised to be sustainable (Simpfendorfer \& Dulvy 2017; NOAA 2016). It supplies more than $90 \%$ of the global trade in the species, the meat being sent to Europe while the fins go to Asia (Wiersma \& Carroll 2018). When decades of overfishing in the Northeast Atlantic caused a 95\% decline, and finally the closure, of the European spiny dogfish fishery, the USA expanded its take in the Northwest Atlantic in the 1990s to fill the demand (Wiersma \& Carroll 2018). More than 95\% of the sharks landed were mature females, the largest (and usually pregnant) dogfish (Rago et al. 1998). The biomass of the female spawning stock declined by 75\% as a result (Wiersma \& Carroll 2018), and the fishery collapsed. However, in 2010 the US Department of Commerce's National Oceanic and Atmospheric Administration (NOAA) declared the fishery rebuilt (meaning that dogfish numbers had increased), and since then has been working to expand it, considering it to be underutilized (Witkin et al. 2015; NOAA 2016; 
St. Gelais \& Costa-Pierce 2016). Spiny dogfish consume some of the same fishes that were depleted by fisheries on the eastern seaboard of the USA, and compete with cod for others. So when cod stocks were severely depleted, dogfish had less competition, and their numbers increased. The expansion of the dogfish fishery was therefore driven in part by the intention to eradicate this competition for fishermen, with the claim that getting rid of spiny dogfish would help restore balance to the ecosystem (St. Gelais \& Costa-Pierce 2016).

As a result, dogfish meat has been marketed in the Atlantic states as a replacement for teleost fish whose stocks have been badly depleted, including cod (Goldfarb 2016; New York Post 2016; Kowacki 2018), even though it is known to be a potential danger to human health (Taylor et al. 2014; St. Gelais \& Costa-Pierce 2016).

Using sharks as a replacement for depleted fish stocks is not a viable solution of that problem, for not only are sharks high on the food chain and of incalculable ecological importance, shark productivity is comparatively very low. The increase in these meso-predators resulted from the elimination of the large sharks (Heithaus et al. 2008), so the only way to restore the ecosystem is to permit the overfished stocks of sharks and cod to recover (World Bank 2017). Further, dogfish are fished mostly by bottom gillnets and trawlers (NOAA 2020), which is highly destructive to the sea floor and could in no way benefit the marine environment (Jones 1992).

The dogfish fishery is also extremely wasteful. In 2018 commercial dogfish landings were estimated at 16.7 million pounds (7.6 Mt), while discards from commercial and recreational sources combined have remained at around 11 million pounds (5.0 Mt) each year over the last decade. In 2014 recreational discards alone totalled 8 million pounds (3.6 Mt) of shark (Atlantic States Marine Fisheries Commission 2018).

Spiny dogfish are slow-growing, cold-water sharks whose numbers increased due to the removal of their predators and competitors. But such increases can be quickly reversed if intensive fishing continues because of the high sensitivity of elasmobranchs to any changes in survival rate (Myers \& Worm 2003; Ferretti et al. 2010). Further, Dulvy et al. (2008) found that the threat to sharks is greater than that predicted by fisheries' assessments and that local analyses may underestimate the risk of the collapse of global stocks. Collapse is particularly likely when vulnerable stocks from just one region are expected to supply $90 \%$ of the world's demand (Wiersma \& Carroll 2018), as is the case here.

The boom and bust pattern of spiny dogfish exploitation is typical of targeted elasmobranch fisheries. Rapidly increasing yields are followed by sudden and extreme declines in catch, which signify not only the fragility of the fishery, but also poor management (Cashion et al. 2019). USA Federal efforts to manage spiny dogfish have been ineffective, hampered by high bycatch and the defiance of scientific advice by the Atlantic states. The stock is currently assessed as 'Endangered' by IUCN (with a declining population trend) on the basis of past and continuing declines, persistent market demand, targeted fishing, increasing discards, and growing pressure to reopen fisheries (Fordham et al. 2016). Nevertheless, US Atlantic spiny dogfish meat, fished by trawlers, bottom gillnets, and bottom longlines in the North West Atlantic, has been certified as sustainable since 2012 (MSC 2020). The history of the fishery suggests clearly that it is not sustainable, and that it will not remain productive for long. 


\subsection{Sustainability in the shark fin trade}

Most species taken in the shark fin trade have never been known to support sustainably-managed fisheries (Fields et al. 2017). However, Simpfendorfer \& Dulvy (2017) claimed that fisheries serving the shark fin market could, with management, be made sustainable for two species: the shortfin mako and blue sharks in the North and South Atlantic, and the blue shark in the North Pacific.

While the Northwest Atlantic Fisheries Organization (NAFO) and ICCAT are responsible for the management of fisheries in the Northwest Atlantic, ICCAT is responsible for the longline fisheries that catch most of the pelagic shark species (Campana 2016). ICCAT represents 52 contracting nations and groups, including the EU, that between them fish more than 127 million hooks each year in the North Atlantic. Their priority is tuna, swordfish, and billfish; sharks are of lesser concern. Member nations provide data of highly variable quality for their fisheries and there are also several major fishing nations fishing the North Atlantic that are not party to ICCAT and provide no shark catch data to anyone.

ICCAT has applied different standards for sharks than for tuna, swordfish, and billfish, which Campana (2016) concluded meant that sharks were considered as a nuisance, not a concern. Until recently, there was no effort to measure or compensate for discards, discard mortality, or hooking mortality. Although it is now required that discards be reported, most contracting parties report very limited data on shark discards, if any.

The same tendency can be seen throughout the history of shark fishing (Ward \& Myers 2005; Campana 2016; Fordham et al. 2016). The priority of the parties to the RFMOs is to maximize the profits of their own fisheries, and managing sharks can reduce those profits (Campana 2016). Even where possible, with few exceptions, RFMOs have not intervened as sharks have been increasingly overfished (Dulvy et al. 2014).

\subsection{The shortfin mako}

In a parallel with many other species, and as a result of industrial overfishing, the mean weight of the shortfin mako taken by longliners fell from $74 \mathrm{~kg}$ in the 1950 s to just $38 \mathrm{~kg}$ in the 1990s (Ward \& Myers 2005). This indicates how seriously the species has been affected by human predation. Like other cold water sharks, shortfin makos are slow growing and have a low reproductive rate, so they are especially vulnerable to overfishing. They are killed for sport as well as for their meat and fins, and have suffered high mortality throughout their range (Ferretti et al. 2010; Byrnes et al. 2017); Rigby et al. 2019). Shortfin makos have a greater landed value than blue sharks, and are retained after capture for use as meat (ICCAT 2020).

Figure 1 shows the shortfin mako shark catches reported to ICCAT in the North and South Atlantic. For the last three years landings from the South Atlantic have exceeded those from the North, where the steady decline over the last 20 years is clear. 


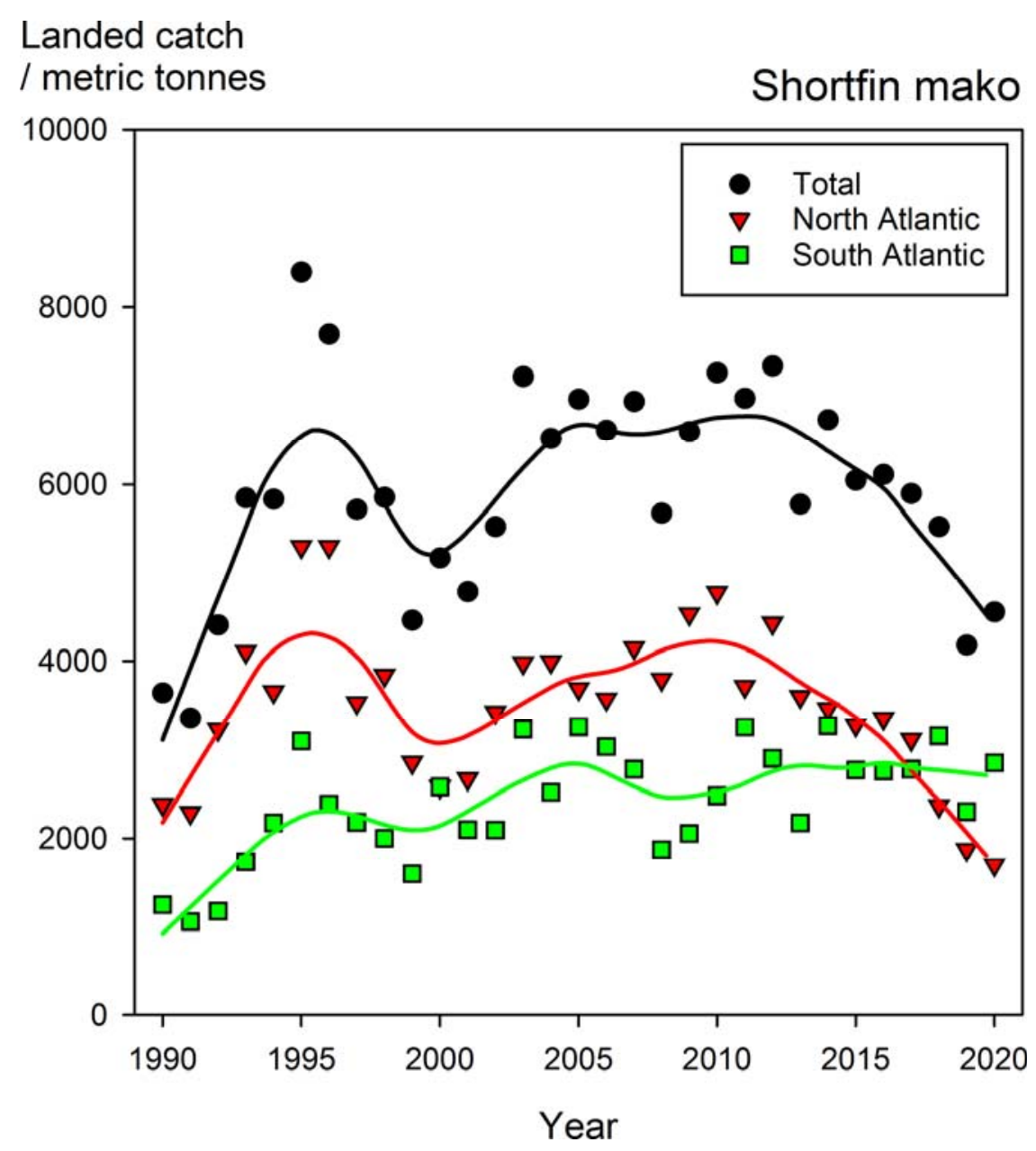

Figure 1: Landings of the shortfin mako shark, as reported to ICCAT. (Smoothed trend lines for eye-guidance.)

The shortfin mako was assessed on the IUCN Red List in 2000 as being 'Near Threatened', reclassified as 'Vulnerable' in 2009, and in 2019 as 'Endangered' worldwide, with a decreasing population trend - this in less than 20 years because effective conservation actions were not taken.

In the North Atlantic, an ICCAT stock assessment in 2017 showed a 90\% probability that the stock was overfished and that overfishing was occurring (ICCAT 2017a). ICCAT noted that fisheries were removing mostly juveniles, but they were not catching mature females, meaning that replacement would not occur. This in turn means that the spawning stock size will keep declining for years even if fishing pressure is reduced. Based on a post-release mortality of $25 \%$, ICCAT recommended a retention ban for live mako sharks, unless there was an observer on board (although how that helps is not clear), and that best handling practices be used prior to the release of live sharks (ICCAT 2017b).

In 2019, ICCAT updated the 2017 projections, noting that landings of blue and mako sharks had significantly decreased. It warned that shortfin mako status was so dire that even if all fishing was stopped immediately their numbers would continue to decline for the next fifteen years, with a probability of only about $50 \%$ that the stock would be rebuilt by 2045 . The probability that it would be rebuilt would not exceed 70\% until 2070, some 50 years from now (ICCAT 2019).

A CITES conference in August 2019 (CITES 2019) found that the situation is the result of thirty years of intensive longline overfishing that removed a high proportion of the juveniles. Hence, as 
older females die, they will not be replaced by younger ones, indicating an impending population collapse. The situation is considered to be the same in the South Atlantic (CITES 2019). CITES listed the shortfin mako in Appendix II, which is intended to protect species that are not under immediate threat of extinction, but require extra protection. However, CITES also noted that since the species is threatened with extinction, it met the Appendix I criteria for full protection. CITES found that fisheries management measures under ICCAT would not halt its decline, and that no other RFMO limits mako catches either, although the species is under the same threats globally (CITES 2019).

The ICCAT 2017 recommendation for a retention ban (ICCAT 2017b) was to come into effect in 2019, but this was blocked by both the USA and the European Union (EU) (ICCAT 2019), which chose to put short-term fishing interests before the need to protect the species. Their failure to respect the RFMO's scientific recommendations was in violation of UNFSA and UNCLOS regulations, which establish a clear duty to protect not only target species, but those caught as bycatch, as well as to refrain from the perpetration of actions which cause damage to the marine environment and threatened species. A duty to cooperate with other States in the conservation of living resources was also violated, which is particularly noteworthy given that both the EU and the USA have taken on the role of policing the rest of the world in terms of IUU fishing (Rosello et al. 2021). However, that detailed analysis indicates that both the USA and the EU are operating at some legal risk, i.e. of being challenged for violating their own laws and therefore actually perpetrating IUU fishing as governments (Rosello et al. 2021).

The EU is responsible, globally, for more recorded shark catches than any other polity because of the large catches of Spain, Portugal and France (India lies second (India 2013)), while the USA is the fifth most prolific shark hunting nation (TRAFFIC 2019), and boasts the biggest recreational shark fishery in the world (Walker 1998).

Finally, in November, 2021, a retention ban was agreed upon, to start in 2022 and extend into 2023. A management plan will be launched, with the goal of achieving MSY by 2070 with a probability of between 60 and 70\%. Total fishing mortality for the shortfin mako in the North Atlantic was set to a maximum of $250 \mathrm{t}$ until new scientific advice is provided to the Commission (ICCAT 2021b).

However, Byrne et al. (2017) found that mortality and post-release mortality of juvenile shortfin mako sharks is significantly higher than fisheries estimates in the North Atlantic. Capture often interrupts ram ventilation (Wegner et al. 2012) and results in severe handling and hooking injuries (Campana et al. 2016). Though best handling practices are recommended (ICCAT 2017b, 2019), it is unrealistic to expect exhausted fishing employees, often working in very poor conditions, to treat those large predators with care when they themselves are not being treated justly. Taiwan is a party to ICCAT, for example, and human rights violations were found on $92 \%$ of its ships (Greenpeace 2020). The survival of the mako shark is more likely, therefore, to be dependent on the swift development of selective fishing gear, than on careful handling of the sharks prior to release.

\subsection{The blue shark}

With 90\% of teleost stocks overfished (World Bank 2017), blue sharks are caught in increasing numbers around the world for their previously low-valued meat (da Silva et al. 2021). In Chile, for example, retention of blue sharks increased almost sixty-fold between 1999 and 2009 (Davidson et al. 2016). In the ICCAT area alone, reported landings of blue shark have increased by a factor of 
about six from 11,300 $\mathrm{t}$ in 1994 to 70,200 $\mathrm{t}$ in 2016 and 68,200 $\mathrm{t}$ in 2018. The blue shark makes up about $90 \%$ of the global catch of elasmobranchs (da Silva et al. 2021) and provides more fins for the shark fin trade than any other species (Clarke et al. 2006b). Fields et al. (2017) estimated that between 34 and 64\% of shark fins traded in Hong Kong are from the blue shark, but the chairman of the Hong Kong Marine Products Association, Ricky Leung Lak-kee, has stated that blue shark fins make up 60 to $80 \%$ of those consumed in Hong Kong (Kao 2017).

Blue sharks dominate the bycatch of longline fisheries (Oliver et al. 2015) and they are considered to be at high risk due to their distribution, which overlaps heavily fished regions (Queiroz et al. 2019). Further, as oxygen minimum zones (OMZs) expand due to global warming, blue sharks may be shifting their distribution patterns into surface waters to avoid deeper, oxygen depleted waters (Vedor et al. 2021). Therefore they are at even higher risk of being caught by surface longliners, who operate mostly above those OMZ depths (Vedor et al. 2021).

Clarke et al. (2007) found that blue sharks were already being taken at rates possibly exceeding the maximum sustainable yield (MSY) between October 1999 and March 2001. Since then, catch rates in the North Pacific have been estimated to be declining at 5\% per year (Clarke et al. 2013), which suggests that the slaughter is unsustainable. Most blue sharks caught in the Atlantic are juveniles (ICCAT 2019), a strong sign of over-exploitation. Similarly, in Peru, of 11,166 blue and mako sharks caught in a longline fishery, $83.7 \%$ were sexually immature and under the legal minimum landing size (Doherty et al. 2014).

In 2017, the blue shark was listed on Appendix II of the CMS (CMS 2020).

In the USA and Canadian swordfish and tuna fisheries in the North Atlantic, blue shark discards approach $100 \%$ because blue shark meat has no commercial value in North America. Yet blue shark catches often exceed catches of the target species. Canada's North West Atlantic pelagic longline swordfish fishery, for example, reports catches of 20,000 swordfish and 100,000 blue sharks annually (Make Stewardship Count 2018), indicating near total wastage. In the North Atlantic some 3 million blue sharks ( 100,000 t) have been estimated to be discarded each year (Campana 2016).

In the Atlantic Ocean, blue shark catches have steadily increased since the 1990s, from roughly $3,000 \mathrm{t}$ in 1990 to more than 73,000 t in 2011, an almost 25-fold increase over 30 years. But although the species is relatively productive, there is no evidence that such a take could be sustainable. Indeed, landings have begun to decline in the North, falling below the take in the South Atlantic for the first time in 2018 (Figure 2).

In 2019, ICCAT considered that the possibilities of blue sharks being overfished, and overfishing occurring, could not be ruled out due to uncertainties in the data, and established TACs for blue sharks in both the North and South Atlantic for the first time.

The EU fleets are most heavily engaged in the targeting of blue sharks in the Atlantic, with Spain and Portugal responsible for 80 - 90\% of all catches there since 1997. As the third-ranking shark fin producer in the world, Spain exported 3,409 t of shark fins to Southeast Asia each year between 2000 and 2011 (Dent \& Clarke 2015). The numbers of fins in Asian markets coming from the North Atlantic greatly exceed the reported catch (Clarke 2008), indicating that there is substantial unreported finning which is not being taken into account by ICCAT. The lucrative shark fin market provides strong motivation. Sharks whose fins have been cut off and then dumped, often still living, back into the sea, are not recorded because most western countries have banned the practice of shark finning. Campana (2016) estimates that the actual numbers of blue sharks being killed are 
four times those reported.

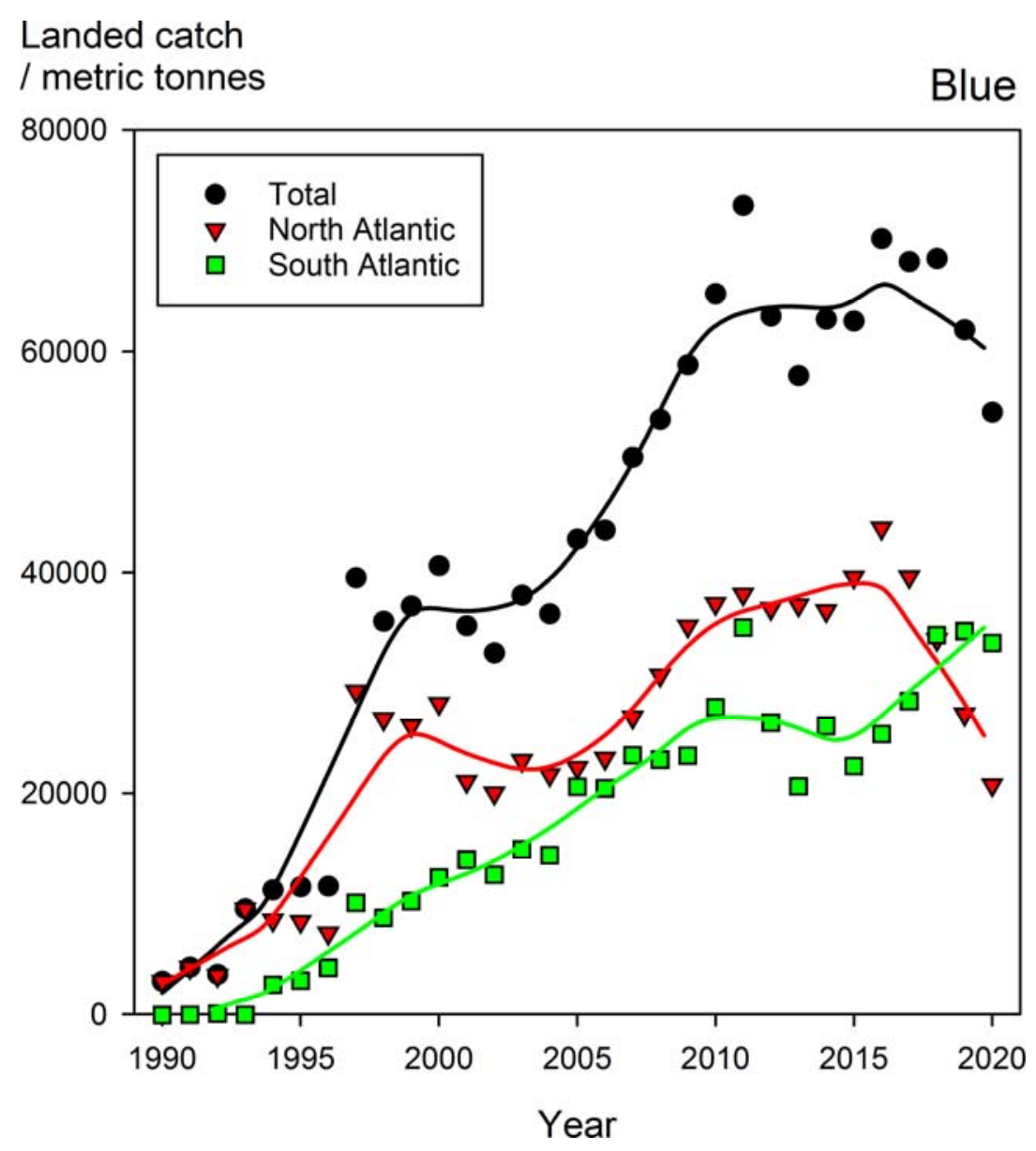

Figure 2: Landings of blue shark as reported to ICCAT. (Smoothed trend lines for eye-guidance.)

Due to the lack of any reliable estimate of the numbers of discarded blue sharks, there is concern that the actual mortality may be much greater than that estimated (da Silva et al. 2021). Further, ICCAT's last blue shark assessment was made in 2015, and though another was planned for 2021, due to the COVID-19 pandemic and the low priority of the species, the assessment has been postponed until 2023 (ICCAT 2021a).

In the absence of any measure to prevent overfishing, or to ensure the rebuilding of overfished stocks, continued depletion appears inevitable. In 2020 the EU approved a proposal from the 2019 ICCAT meeting for an active management of shark stocks (EU Parliament 2020). Since the EU fleets are the main players in this business, it remains to be seen what this will involve for blue sharks.

A further problem with the prediction of sustainability for the blue shark in the Atlantic Ocean (Simpfendorfer \& Dulvy 2017) is that it is based on MSY, defined as the

"current biomass being greater than that required to achieve MSY or current fishing mortality being less than that which will yield MSY” (Simpfendorfer \& Dulvy 2017).

But MSY is estimated from actual landings, so it is hardly applicable to a largely discarded species (Campana 2016). Further, this method is no longer considered to be applicable to fisheries that are overfished and require stock rebuilding: spawning biomass first has to be restored, then the 
mortality from fishing must always be lower than mortality to maintain MSY (Tsikliras \& Froese 2019).

Just two years after Simpfendorfer \& Dulvy (2017) claimed that the shortfin mako and blue shark fisheries in the North and South Atlantic Ocean were "bright spots of sustainable shark fishing," the unfolding trends have indicated that they were wrong.

The history of shark fishing underlines the findings of Agrawal (2001), that managing the commons is impossible. With the Atlantic Ocean being situated between the continents of Europe and America, in the heart of what is considered the civilized western world, one would expect it to receive the most exceptional management of fish and shark stocks. However, the above examination of the situation there clearly illustrates the failure of RFMO shark management.

\section{Fishing economics}

The fishing industry is currently propped up by an estimated US\$35.4 billion in subsidies (Sumaila et al. 2019). China provides the highest subsidy among nations, at $21 \%$ of the total, followed by the USA at $10 \%$, and the Republic of Korea at $9 \%$. These subsidies far exceed the profits from their fishing (Sala et al. 2018). The only fishing fleets that are currently profitable are the longliners and purse-seiners which target the highest-valued marine animals: tuna and sharks (Sala et al. 2018). Fully 54\% are unprofitable, especially the largest fishing fleets. The current scale is enabled only by those large government subsidies (Sala et al. 2018; Sumaila et al. 2019). For example, the diesel for the long distance fishing fleets of the EU is paid for by subsidies, which allow them to go to the distant Indian Ocean and the Western and Central Pacific where, with their larger vessels and superior technology, they compete with the local fisheries for the remaining stocks of fish (Sala et al. 2018, Sumaila et al. 2019). Deep-sea trawling, which is one of the most destructive fishing practices, is especially supported by subsidies, yet $32 \%$ of deep-sea trawling is unprofitable (Sumaila et al. 2010, 2019; Norse et al. 2011; Sala et al. 2018).

Evidently, high seas fishing activity would be completely transformed if subsidies were halted. For example, Spain, a top provider of blue shark fins to Asia, has its most profitable fisheries in the Western Indian Ocean, the Southeast Pacific, and the Southwest Pacific, far from its own EEZ. Many of its distant purse-seine fisheries would not be profitable without subsidies, and its high seas bottom trawling would be unprofitable everywhere without subsidies (Sala et al. 2018).

Global studies by the World Bank and FAO, Sunken Billions (2008) and Sunken Billions Revisited (2017), have reported that overfishing has resulted in a loss of about US\$83 billion yearly. It found that fishing effort must be reduced to get the best economic result for solving the evolving global fisheries crisis. The fundamental reforms that are required must follow two parallel and simultaneous paths: (a) stock recovery, which would require giving depleted and over-exploited stocks a chance to recover, primarily by reducing fishing effort, and (b) restoring the integrity of the habitats on which the stocks depend (including mangroves, coral reefs, and seagrass beds).

This is the course of action which should be taken. However, the shark fin trade has made these top and middle predators valuable, so global fisheries are targeting them instead, despite their high ecological importance and the toxicity of their fins and meat.

Clearly, shutting down a large proportion of the world's industrial fishing fleet will be disruptive and social unrest is predicted because millions of fishers will have to switch to other occupations. 
However, the fishing subsidies that have encouraged overfishing in the past could be used to help ease the social transition (Arnason et al. 2008; World Bank 2017; IPBES 2019).

\section{Fisheries management}

It has been known for decades that sharks are vulnerable to overfishing (e.g. Travis 1961; Walker 1998; Castro et al. 1999), that they are under high fishing pressure (Myers \& Worm 2003; Worm et al. 2013), are of high ecological value (Stevens et al. 2000; Ferretti et al. 2010), and that those accessible to commercial fishing fleets are threatened with global extinction (Dulvy et al. 2014; Pacoureau et al. 2021). One scientist after another has advised over many years that species-specific records are a necessary prelude to the possibility of the sustainable management of sharks, and that collecting data, especially in data-poor regions, should be a priority (Stevens et al. 2000; WardPaige et al. 2012; Oliver et al. 2015; Pauly \& Zeller 2015). Since industrial fishing fleets operate over vast regions, and usually in international waters (Kroodsma et al. 2018), the availability of accurate data, and international cooperation in its collection, is necessary on a global scale, for both the monitoring and management of elasmobranch catch and bycatch at the species-specific level (Oliver et al. 2015; Davidson et al. 2016).

Nevertheless, it was found in 2015 that of the top ten shark fishing nations, only the USA had kept reasonable records, and only half had kept any records at all (Oliver et al. 2015). Lam \& Sadovy de Mitcheson affirmed in 2011 that at that time Chinese shark catch data were classified as state secrets and such data continue to be unavailable publicly. Thus, although China fishes more intensively than any other nation (Sala et al. 2018), its large shark catches have not been included in any fisheries’ assessments.

\subsection{The impossibility of establishing global sustainability}

Sustainable shark fishing advocates broadcast the idea that sharks are being fished sustainably in spite of the established facts. In the USA, The Sustainable Shark Alliance (Vaness 2019), a "coalition of shark fishermen and seafood dealers" advocates the Sustainable Shark Fisheries and Trade Act (SSFTA). Advertised as a "practical solution” that would allow American fishermen to continue to profit from the shark fin trade, SSFTA claims that it will create a

"transparent certification program for countries seeking to import shark products into the United States,"

by requiring that they have

"shark and ray management policies comparable to those under the U.S. MagnusonStevens Act”.

This is supported by a variety of shark fisheries scientists (Rutger 2018), yet no one has described how all 1,107 Chondrichthyan species (as well as all fish species) could be sustainably managed throughout the entire world.

The problems of such management would include:

- how the determination of what is a sustainable catch rate for every shark fishery in the world will be made

- how the baseline will be determined

- how management plans will be implemented

- how they will be funded

- how they will be enforced 


\section{- how RFMOs could be made to agree to base quotas and rules}

Massive data collection projects would need to be organized - standardized, implemented, monitored and funded on a global scale. Then, when laws are in place and enough data has been collected to determine what the sustainable catch rates might be, development and funding of fisheries management plans would need to be put in place, including staffing, training, and purchase of equipment. These are expensive to set up and operate. Expenses range from those for scientific advice and management, to enforcement, including monitoring, control, and surveillance; they can reach $14 \%$ of the value of landings (World Bank 2017). Most of the cost is borne by the public sector, while the benefits are concentrated on the fishers (World Bank 2017; Ferretti et al. 2020).

All that is involved in SSFTA—putting American practices into play on a global scale-would need to be maintained long-term. Yet neither the necessary funds, nor an international organization that could create such a cooperative network, exist. It would require every country to keep politics, financial self-interest, corruption, and criminality, out of the process.

The refusals of the USA and the EU to follow ICCAT's recommendations for an immediate retention ban on shortfin mako in the North Atlantic in 2019 (ICCAT 2019) provides an illustration of the willingness of states to ignore laws in the absence of a higher authority. It is also a telling example of how difficult it is to protect high-valued animals, no matter how large is the class of vertebrates involved, or how important they are ecologically.

The extent of surveillance and monitoring that would be required, as well as its cost, is also prohibitive, but essential to any claim to the sustainable management of all shark fisheries, and not just the official target species. Even 100\% human observer coverage on all vessels would be insufficient to ensure that finning or illegal retention does not take place (Human Rights at Sea 2020; McVeigh \& Firdaus 2020; Greenpeace 2020). Due to the illegal character of the shark fin trade and the huge profits associated with it, observers have even been murdered (Human Rights at Sea 2020). Severe human rights abuses are a serious problem, especially on the long distance fleets of WCPFC, including on MSC-certified fisheries vessels (Greenpeace 2020; Human Rights at Sea 2020). As is apparent from the shark fin industry, illegal, unreported, and unregulated activities tend to accompany the abuse of, and crimes against, humans (IPBES 2019). Both authors have been threatened (BWD in Hong Kong, with violence by a shark-fin trader at a public meeting, and IFP by a fisherman with death if he caught her alone at sea, during her ethological study of shark behaviour in French Polynesia).

In Asian consumer nations there is little government interest in regulating the shark fin market and the resources required to do so are simply not in place (Sadovy de Mitcheson et al. 2018). Shark fin consumers can afford to pay high prices for them and are quite unconcerned about sustainability.

The involvement of fisheries worldwide and the participation of criminal networks in a trade driven by high prices and rich customers, contrasted with the catastrophic, ongoing depletion of the animals supplying the fins (Fields et al. 2017), makes the current global hunt for sharks to supply the shark fin trade not only unsustainable but a severe threat to the health of global aquatic ecosystems.

Even the pressure from artisanal and subsistence fishing in remote regions, or shark netting programs to 'protect' beaches, can cause serious depletion of large coastal sharks (Ferretti et al. 2010). Since the stocks of most elasmobranchs have collapsed, and in view of their low productivity, truly sustainable shark fishing would therefore now require the enforcement of near- 
zero shark mortality globally to allow both top predators and their small elasmobranch prey to recover (Ward-Paige et al. 2012; Davidson et al. 2016). Clearly this would not support even a tiny fraction of the shark fin trade.

\subsection{The concept of 'sustainable use'}

The United Nations Convention on Biological Diversity of 1992 defines the sustainable "utilization of biodiversity" as

"use of components of biological diversity in a way and at a rate that does not lead to the long-term decline of biological diversity, thereby maintaining its potential to meet the needs and aspirations of present and future generations (Article 2).” (CBD 1992)

CITES was originally founded to limit industry destruction of biodiversity, and its Convention uses a biocentric set of values with regards to 'sustainable use' (Cooney 2007) in which biodiversity is considered to have an intrinsic value that must be preserved in a state of health. However, 'sustainable use' is often given a more anthropocentric set of values, in which human use has greater importance than the intrinsic value of biodiversity (Cooney 2007).

Indeed, fisheries law tends to take an anthropocentric view, being based on the concept of MSY, without regard for ecosystem effects. The EU Common Fisheries Policy (EU Monitor 2002), for example, in part defined 'sustainable use' as: "exploitation of living aquatic resources that provides sustainable environmental, economic and social conditions”. For comparison the MagnusonStevens Act (MSA 1976) (which regulates fisheries in the USA) defined the "optimum yield" from a fishery as the amount of fish that will provide "the greatest overall benefit to the Nation, particularly with respect to food production and recreational opportunities” (MSA 1976), while the rider: "and taking into account the protection of marine ecosystems" seems to receive little attention for chondricthyans in practice. This "optimum yield" "is prescribed on the basis of the maximum sustainable yield from the fishery”. Benefit to industry, and by inference, humanity, is placed before the need to maintain ecosystems in good health. The lack of concern for biodiversity is especially evident in the case of highly uncertain shark assessments when the base values for calculating MSY are grossly inaccurate (Campana 2016) and although up to 100\% (in the case of blue sharks) of the catch may be discarded, MSY is still only calculated on landings.

As is evident in many ways in the treatment of fish and their environment, the fishing industry tends to view itself as the sole legitimate user, and in effect the owner, of living marine resources (Preikshot \& Pauly 2005). Fisheries science and management has focused on target populations and not the species caught as bycatch, resulting in ecological damage and extreme declines in abundance and biodiversity. Fisheries stock assessment scientists have traditionally worked in government laboratories for fisheries, with a narrow focus that dismissed conservation issues, even though their governments were signatories to binding conservation agreements. This remained the case even after commercial fish stocks became depleted (Preikshot \& Pauly 2005).

In political science, biodiversity interests are practically non-existent. In 2006, Agrawal \& Ostrom found that in the previous twenty years the top political science journals had published only one article that focused on biodiversity, out of more than 2000 papers. Further, in the top five political science departments in the USA, not a single faculty member counted biodiversity conservation among his or her interests (Agrawal \& Ostrom 2006). 
This situation reveals an extremely anthropocentric approach to the conservation of biodiversity in general and sharks in particular. This is aggravated by the territorial position taken by fisheries of ownership of the stocks, and the assumed right to take them no matter how depleted they become.

To most people, the idea of sharks being fished sustainably suggests that they and their environments are being kept in a state of health for future generations. However, this is far from being the case. In fisheries, 'sustainable use' is not being defended against 'unsustainable use', but it is being defended against the effective protection of sharks. This continues to be the case even though the species accessible to industrial fisheries are now threatened with extinction and therefore fulfil the criteria for CITES Appendix I listing.

As well as being exemplified by the Sustainable Shark Alliance and its dogma, this position is evident in the many pro-shark fishing papers recently published, in which shark depletion is described, yet continued fishing is still promoted (Simpfendorer \& Dulvy 2017; Shiffman \& Hueter 2017; Pacoureau et al. 2021). The sustainable use advocates fail to be precise about when it is time to stop using the 'resource'. The IUCN defines this situation as "Position 4", which is "deliberate misuse of the terminology of sustainable use". In fact, it has been noted that

"[the phrase] supporting sustainable use can be used in order to justify any specific use, regardless of its sustainability. This will usually be used as a political or rhetorical strategy to defeat opposition to use ... it has no biocentric rationale, and ... it is not consistent with a conservation strategy. It will be motivated by anthropocentric reasons, to justify gaining the benefits of use to humans" (Cooney 2007).

According to IUCN policies, the actions that must be reduced are:

- the use of biodiversity and its components at unsustainable levels

- the use of components of biodiversity causing environmental damage

- consumption of anything that impacts unsustainably on biodiversity (Cooney 2007).

These are not being advocated for sharks by fisheries’ shark scientists.

\subsection{Instinct versus science}

The willingness of the fishing industry to pillage without regard for the health of the biosphere and the resulting ecological harm (Travis et al. 2014), the level of bycatch that has been treated as tolerable (Harrington et al. 2005; Ferretti et al. 2010; Oliver et al. 2015), and the readiness to put short-term financial interests first (Fordham et al. 2016; St. Gelais \& Costa-Pierce 2016; Shiffman \& Hueter 2017; ICCAT 2019, Rosello et al. 2021) reveals its failure to consider biodiversity to even a small degree. Deep-sea trawlers 'mine' ecosystems in the knowledge that they will not recover (Sumaila et al. 2010; Norse et al. 2011). Although the danger to marine life posed by abandoned ('ghost') fishing nets has long been recognized, for more than three decades the fishing industry has trailed nets to significant depths below dFADs, killing large numbers of sea turtles and sharks. This mortality from entanglement has been ignored by fisheries scientists and RFMOs alike (Filmalter et al. 2013; Stelfox et al. 2021). Drifting FADs are regularly abandoned by the fleet that launched them. They are able to drift for as long as two years, can cover distances of more than 10,000 km (Hanich et al. 2019), and badly damage the shore, especially delicate environments such as coral reefs and mangroves, when they beach (Balderson \& Martin 2015).

Yet fish from such fisheries, as well as fish from those practicing shark finning and other highly wasteful and damaging pursuits, have been certified as "sustainable" by MSC, although the body 
claims to use a high standard in recommending only sustainable seafood to a trusting public. However, in practice, it is applying much lower industry standards for certification (MSC 2020b; Kearns 2015; Edwards 2018).

It has been 'scientifically' argued that fishermen should treat fish as they wish because they are predators and part of the food chain (Diggles et al. 2011). In contrast, our civilization prides itself on the idea that humanity uses reason in its decision-making, rather than following its instincts. But Diggles has reminded us of the true situation: the world's fishermen are in the same position as any other predator that is in the process of eliminating its prey. With the human population as overgrown as it is, it has been known for decades that the moment would come in which no wild prey could sustain us (Meadows et al. 1972).

We have the capacity to recognize the difference between instinctual drive and reasoned thought, yet reason (i.e. science) is often rejected in negotiations. Territorial interests supervene and limit international cooperation (Lorenz 1963), which carries over into the management of globally important species. Such barriers must be overcome, otherwise the current pattern of species depletion, extinction, and the unravelling of the planet's ecosystems will continue and accelerate, eventually to the severe detriment of humanity (Barry 2014; IPBES 2019; Dasgupta 2021).

That one soup recipe, in just one of the world's many cultures, could have had such a serious effect on the status of as many species as are represented by the class of Chondrichthyes is a telling indictment of the priorities of humanity. Participation in such a market is an ethical question. The way the industrialized western nations have joined the hunt for sharks to profit from such a market highlights the need to address this facet of the problem.

\section{Conclusions}

The literature documents an experiment in mega-death that must not be allowed to continue. The current tendency to turn to fishing sharks because the shark fin trade has made them profitable, instead of concentrating on the recovery of the gravely depleted teleost fish stocks and their habitats (with the goal of long-term yields from healthy fish stocks in the future), is a dangerous course which should not be pursued. Sharks will go the way of the teleost fish, and much more quickly, if the current trend continues. No lessons have been learned from the demise of Grand Banks cod (Mason 2002) and North Sea herring (Dickey-Collas 2010) it seems.

Given the market interplay of supply and demand, wherein the desire for money fuels the targeted hunt for sharks, and rich customers supply it, the way to stop the slaughter is to stop the shark fin trade itself, which could best be done through a ban on International trade. Stopping demand, and addressing bycatch and IUU fishing, are key aspects of this.

\subsection{Protection from International trade}

All sharks, manta rays, devil rays, rhino rays, and chimaeras, as well as their parts, require immediate protection. The illegal character and the high economic incentives associated with the shark fin trade heighten its danger for the increasingly depleted large predators supplying it, while the takes of shark liver oil, with at-sea processing, is of the same character (Sea Shepherd 2017a, b). The ineffectiveness of the measures taken to date, including CITES Appendix II listings, indicates that the protection afforded to accessible species must be significantly improved. Therefore, a 
CITES Appendix I listing should immediately be granted to provide the needed protection. The shark fin trade takes all fins, therefore all should be listed. There is already a precedent in listing look-alike species as a counter to deception (Vincent et al. 2013).

The claim that there is insufficient data to justify listings on Appendix I does not hold up in the face of the huge weight of evidence of over-depletion revealed by a study of the literature. It provides an alarming warning regarding what is occurring and lays out more than sufficient reason for that listing, especially given the impossibilities of assessing the status of sharks accurately or managing the global commons of the High Seas. Sharks must be treated as protected wildlife internationally, rather than as a resource of interest to commercial fisheries. Critically, international cooperation is needed. A binding international treaty to protect sharks, as well as threatened biodiversity in general, should be the immediate goal (Dasgupta 2021).

Protection of sharks from international trade would benefit local communities who depend on the sea for their protein. In artisanal fisheries, the elasmobranch catch is generally fully-utilized (Oliver et al. 2015). With no shark exports, the market would remain local, and prices would not be jackedup to export levels. Those in industrial nations, many of whom are already eating too much protein, will choose something else, including plant protein, if fish and shark meat is not on the menu.

A CITES I listing for sharks would greatly simplify management and policing by eliminating the need to identify illegally-caught species, or parts thereof, at border crossings, as well as the continuous demands for more species-specific information in the various regions as required by "Non-detrimental" findings in the case of Appendix II listings. Such species data is expensive, difficult, and too often impossible to get, while its absence delays action under current rules, and the trade continues. A telling example is the way ICCAT postponed the stock assessment of the blue shark, claiming that it lacked the time and resources to get the scientific information necessary to manage this important species.

Shark fin trade bans should be adopted as widely as possible. A trade ban is easier to enforce than fishing regulations, while taking away the enormous profit, and thereby the incentive, to catch sharks. For example, in the USA, the Shark Fin Trade Elimination Act has passed through Congress, and at this writing is awaiting passage in the Senate. Fourteen states have banned shark fins, and Florida has also passed an import ban on fins in 2020. There is a trade ban in Canada, requiring all shark fins to remain naturally-attached to the body of the animal for import and export. Political pressure is being applied to effect a trade ban in Europe (pers. comm. Alex Hofford).

Honest labelling of seafood products should be required for transparency and traceability. There would be a significant decrease in the 'demand' for shark meat if it were actually labelled as shark meat.

\subsection{Fishing effort reduction}

Fishing effort must be diminished by a large proportion to permit the damaged ecosystems of oceans, coral reefs, lagoons, mangroves, estuaries, rivers, lakes, and coastlines to recover. All fishing subsidies must end. The money should be used instead to help fishermen switch to other occupations, including, for example, ecotourism or the planting of food crops, and to police the shores and reefs they once fished. Severe sanctions, including heavy fines and vessel seizures, should be levied on violators, and those revenues re-invested in policing and education. 
A radical change is needed to ensure that fishers can sell their catch at a fair price to make a living while neither overfishing nor damaging the environment. Educating them to protect their damaged sea coast is an option that has been found to be highly successful (Alcala 1998). The installation and protection of MPAs helps to increase the abundance of fish in adjacent areas, which will ultimately help to secure income for them.

Deep sea fishing should be permanently banned and fishing methods must be transformed in such a way that bycatch of non-target species is completely avoided. In the meantime, shark bycatch taken by longliners and trawlers should be reduced using available methods (Kaplan et al. 2007; Erickson \& Berkeley 2008; Oliver et al. 2015; Pacoureau et al. 2021), and 'best handling' practices used as much as possible to ensure that the highest possible number of sharks survive mandatory release. The inevitable reduction in fishing efficiency and the increased costs thereby incurred will mean that consumers will have to pay higher prices to eat fish. But fish provide a high quality protein, and a higher price would reflect more truly the value of such wild prey. A global shift towards selective fishing methods, and away from today's efficient, but unselective and destructive methods, must be an objective if we want the remaining biodiversity in our oceans to survive beyond this century (Reid et al. 2016; Zhou et al. 2019).

In addition, at least 30\% of the ocean should be set aside to recover as MPAs (O’Leary et al. 2016). For pelagic species of sharks, large MPAs and no-take zones that include the High Seas are required for effective protection because most are highly migratory. Queiroz et al. (2019) concluded that there is a particularly urgent need for conservation and management measures at high-seas hotspots of shark space. Therefore, designation of such MPAs should take the high degree of spatial overlap between sharks and industrial fishing vessels into consideration, especially in those areas that attract fish, because of their favourable productivity and temperature profiles (Baum 2019). Coastal MPAs must be managed effectively as no-take zones and large enough to encompass the ranges of the resident sharks, ensuring that they are protected at all times (Dwyer et al. 2020).

\subsection{RFMO policies}

More scientific observers should be deployed by RFMOs (Campana 2016, Baum 2019). However, given the increasing numbers of human rights violations, disappearances, and murder of observers (Human Rights at Sea 2020), they should not be used for enforcement of regulations nor compliance monitoring. To effect this, there are now remote electronic monitoring tools available which are tamper-proof and can cover all activities on board. Monitoring of landings and transshipment activities needs to be mandatory, as well as positioning data via the Automatic Identification System (AIS) for all fishing vessels. The equipment should be installed in such a way that it cannot be switched off (Sumaila et al. 2020). Implementation of a comprehensive monitoring and surveillance system combining both human observers and remote electronic monitoring should be a priority task for all RFMOs (Ewell et al. 2020).

RFMOs should be required to respect human rights, and to address slavery, as well as unsafe and inhumane working conditions. At their own expense, they should be required to keep track of stocks through stock assessments by species and geographic region, update them regularly, and mandate catch limits. Landings should be monitored, and species-specific records kept. The pervasive problem of IUU fishing should be addressed globally, through all means available. 


\subsection{Cultural change}

Change can also come through cultural shifts. Such a change with respect to shark fin soup is already ongoing in China (Sadovy de Mitcheson et al. 2018). It needs to be strengthened there and in other shark fin consumer countries. Although demand is decreasing in China and Hong Kong, it is growing in Thailand, Japan, and Malaysia (Dent \& Clarke 2015). Removing shark fin from menus and retail markets in consumer countries is of top priority (Sadovy de Mitcheson et al. 2018).

\subsection{True sustainability}

There must be a shift in attitude towards the management of the biosphere in the interests of sustainability, not of sharks alone, although they may be taken as key indicators, but to permit our civilization to continue on in good health. The domination by industry must end if the planet's aquatic ecosystems are to be saved from ecological collapse (IPBES 2019; Dasgupta 2021).

If history has taught us anything, no wild animal can withstand targeted industrial-scale hunting long term—not whales, not sea turtles, not fish, and certainly not sharks.

Acknowledgments: We thank Iris Ziegler for giving us much information about the shark fishing industry, and for providing Table 1. Many thanks to Alex Hofford and Keith DP Wilson for reading an early draft and making helpful suggestions. We are grateful to Dr. José I Castro, Randall Arauz, Mary O’Malley, and Stefanie Brendl for their insightful input on a variety of the political aspects of shark conservation. 


\section{References}

Agnew DJ, Pearce J, Pramod G, Peatman T, Watson R, John R. Beddington JR, Pitcher TJ (2009) Estimating the worldwide extent of illegal fishing. PLoS ONE 4(2): e4570. doi.org/10.1371/journal.pone.0004570

Agrawal A (2001) Common Property Institutions and Sustainable Governance of Resources. World Development 10(29): 1649-1672.

Agrawal A, Ostrom E (2006) Political science and conservation biology: a dialog of the deaf. Conserv. Biol. 30(3): 681-682.

Alcala AC (1998) Community-based coastal resource management in the Philippines: a case study. Ocean Coast. Manag. 38:179-186.

Amorim AF, Arfelli CA, Fagundes L (1998) Pelagic elasmobranchs caught by longliners off Southern Brazil during 1974-97: an overview. Mar. Freshw. Res. 49, 621- 632.

Animal Welfare Institute (2019) International Shark Finning Bans and Policies awionline.org/content/international-shark-finning-bans-and-policies (accessed 14 August 2020)

Arauz R (2018) NGOs adverse MSC Sustainable Fisheries Certification granted to Western and Central Pacific Tuna Fishery. www.make-stewardship-count.org/ngos-adverse-msc-sustainablefisheries-certification-granted-to-western-and-central-pacific-tuna-fishery (accessed 28 December 2021)

Arnason R, Kelleher K, Willmann R (2008) The Sunken Billions: The Economic Justification for Fisheries Reform. Joint publication of the World Bank and the FAO. ISBN978-0-8213-7790-1.

Atlantic States Marine Fisheries Commission (2018) Spiny Dogfish. www.asmfc.org/species/spinydogfish (accessed 17 April 2020)

Balderson SD, Martin LEC (2015) Environmental impacts and causation of 'beached' Drifting Fish Aggregating Devices around Seychelles Islands: a preliminary report on data collected by Island Conservation Society. IOTC-2015-WPEB11-39

Baum J (2019) Industrial fishing boats leave few safe havens for sharks on the high seas. Nature 572, 449-450 doi: 10.1038/d41586-019-02357-2

Barcia LG, Argiro J, Babcock EA, Cai Y, Shea SKH, Chapman DD (2020) Mercury and arsenic in processed fins from nine of the most traded shark species in the Hong Kong and China dried seafood markets: The potential health risks of shark fin soup. Mar. Pol. Bull., 157: 111281 doi.org/10.1016/j.marpolbul.2020.111281

Barry G (2014) Terrestrial ecosystem loss and biosphere collapse. Manag. Environ. Qual. 25(5):542-563. doi.org/10.1108/MEQ-06-2013-0069 
Bascomte J, Melián CJ, Sala E (2005) Interaction strength combinations and the overfishing of a marine food web. Proc. Natl. Acad. Sci. 102(15):5443-5447.

doi.org/10.1073/pnas.0501562102

Biery L, Pauly D (2012) A global review of species specific shark fin to body mass ratios and relevant legislation J. Fish Biol. 80 (5): 1643-1677 onlinelibrary.wiley.com/doi/abs/10.1111/j.10958649.2011.03215.x ～(accessed 10 March 2021)

Booth H, Pooley S, Clements T, Putra, MIH, Lestari WP, Lewis S, Warwick L, Milner-Gulland EJ (2020) Assessing the impact of regulations on the use and trade of wildlife: An operational framework, with a case study on manta rays. Glob. Ecol. Conserv. 22: e00953. doi.org/10.1016/j.gecco.2020.e00953.

Byrne ME, Cortés E, Jeremy J. Vaudo JJ, Harvey GCM, Sampson M, Wetherbee BM, Shivji M (2017) Satellite telemetry reveals higher fishing mortality rates than previously estimated, suggesting overfishing of an apex marine predator. Proc. Royal Soc. B 284: 20170658.

Campana SE (2016) Transboundary movements, unmonitored fishing mortality, and ineffective international fisheries management pose risks for pelagic sharks in the Northwest Atlantic. Can. J. Fish. Aquat. Sci. 73:1599-1607.

Campana SE, Joyce W, Fowler M, Showell M (2016) Discards, hooking, and post-release mortality of porbeagle (Lamna nasus), shortfin mako (Isurus oxyrinchus), and blue shark (Prionace glauca) in the Canadian pelagic longline fishery. ICES J. Mar. Sci. 73: 520-28.

Cardeñosa D, Fields AT, Babcock EA, Zhang H, Feldheim K, Shea SKH, Fischer GA, Chapman DD (2018) CITES-listed sharks remain among the top species in the contemporary fin trade. Conserv. Lett.. 11:e12457 doi.org/10.1111/conl.12457

Cardeñosa D (2019) Genetic identification of threatened shark species in pet food and beauty care products. Conserv Genet 20:1383-1387. 20, 1383-1387 doi.org/10.1007/s10592-019-01221-0

Cashion MS, Bailly N, Pauly D (2019) Official catch data under-represent shark and ray taxa caught in Mediterranean and Black Sea fisheries. Mar. Pol. 105:1-9. doi.org/10.1016/j.marpol.2019.02.041.

Castro JI, Woodley CM, Brudek RL (1999) A Preliminary Evaluation of Status of Shark Species. FAO Fish. Tech. Pap. 380. Food and Agriculture Organization, Rome.

Castro JI (2017) The origins and rise of shark biology in the 20th century. Mar. Fish. Rev. 78: 1433. Chabrol R, Nouvian C (2012) The hideous price of beauty. An investigation into the market of deep-sea shark liver oil. Bloom Association www.bloomassociation.org/en/wpcontent/uploads/2013/10/ENG_Squalene_4-pager.pdf (accessed 4 June, 2021) 
CITES (2019) Supplementary Information on CITES COP 18 Proposal 42: Confirming that shortfin and longfin mako sharks fully meet the criteria for inclusion on CITES Appendix II. Paper presented at Eighteenth Meeting of the Conference of the Parties, Geneva, Switzerland, June 17-28; CoP18 Inf. 40, 1 and 6. cites.org/sites/default/files/eng/cop/18/inf/E-CoP18-Inf-040.pdf (accessed on 12 December 2021).

Clarke S, Magnussen JE, Abercrombie DL, McAllister M, Shivji M (2006) Identification of shark species composition and proportion in the Hong Kong shark fin market based on molecular genetics and trade records. Conserv. Biol. 20:201-211.

Clarke S, Murdoch K, McAllister M, Milner-Gulland EJ, Kirkwood GP, Michielsens C, Agnew DJ, Pikitch EK, Nakano H, and Shivji MS (2006) Global estimates of shark catches using trade records from commercial markets. Ecol. Lett.. 9 (10): 1115-1126 doi.org//10.1111/j.14610248.2006.00968.x.

Clarke S, Milner-Gulland EJ, Bjørndal T (2007) Social, economic and regulatory drivers of the shark fin trade. Mar. Resour. Econ. 22:305-327.

Clarke S (2008) Use of shark fin trade data to estimate historic total shark removals in the Atlantic Ocean. Aquat. Living Resour. 21: 373-381 doi.org/10.1051/alr:2008060

Clarke SC, Harley SJ, Hoyle SD, Rice JS (2013) Population trends in Pacific Oceanic sharks and the utility of regulations on shark finning. Conserv Biol 00: 1-13. doi.org/10.1111/j.15231739.2012.01943.x

CBD: Convention on Biological Diversity (1992)

https://www.cbd.int/sustainable/introduction.shtml (accessed 14 December, 2021)

Convention on the Conservation of Migratory Species of Wild Animals (2020) www.cms.int/en/species?field_species_class_tid=1857 (accessed 19 August 2020)

Cortés E, Neer JA (2006) Preliminary reassessment of the validity of the $5 \%$ fin to carcass weight ratio for sharks. Collect. Vol. Sci. Pap. ICCAT 59(3): 1025-1036.

CREMA (2018) Costa Rica, Don't Export that Pile of Hammerhead Shark Fins. www.cremacr.org/en/policy-advocacy/campaigns/costa-rica-dont-export-that-stockpile-ofhammerhead-shark-fins/ (accessed 10 March 2021)

Dasgupta P (2021) The Economics of Biodiversity: The Dasgupta Review. Abridged Version. (London: HM Treasury).

da Silva TEF, Lessa R, Santana FM (2021) Current knowledge on biology, fishing and conservation of the blue shark (Prionace glauca). Neotropical Biol. Conserv. 16(1): 71-88. doi.org/10.3897/neotropical.16.e58691 
Davidson LNK, Krawchuk MA, Dulvy NK (2016) Why have global shark and ray landings declined: improved management or overfishing? Fish Fish. 17:438-458 doi.org/10.1111/faf.12119

Dent F, Clarke SC (2015) State of the Global Market for Shark Products. FAO Fish. Tech. Pap. 590

Dickey-Collas M, Nash RDM, Brunel T, van Damme CJG, Marshall TC, Payne MR, Corten A, Geffen AJ, Peck MA, Hatfield EMC, Hintzen NT, Enberg K, Kell LT, Simmonds JE (2010) Lessons learned from stock collapse and recovery of North Sea herring: a review. ICES J. Mar. Sci., 67(9):1875-1886 doi.org/10.1093/icesjms/fsq033

Diggles BK, Cooke SJ, Rose JD, Sawynok W (2011) Ecology and welfare of aquatic animals in wild capture fisheries. Rev Fish Biol Fish 21:739-765.

Doherty PD, Alfaro-Shigueto J, Hodgson DJ, Mangel JC, Witt MJ, Godley BJ (2014) Big catch, little sharks: Insight into Peruvian small-scale longline fisheries. 4(12): 2375 - 2383 Ecol. Evol. doi.org/ 10.1002/ece3.1104.

Drumm R (1996) In the Slick of the Cricket. BookSurge Publishing, Charleston. USA

Dulvy NK, Baum JK, Clarke S, Compagno LJV, Cortés E, Domingo A, Fordham S, Fowler S, Francis MP, Gibson C, Martínez J, Musick, JA, Soldo A, Stevens, J.D, Valenti S (2008) You can swim but you can't hide: the global status and conservation of oceanic pelagic sharks and rays. Aquat. Conserv. Mar. Freshw. Ecosyst. 18:459-482. doi.org/10.1002/aqc.975

Dulvy NK, Fowler SL, Musick JA, Cavanagh RD, Kyne PM, Harrison LR, Carlson JK, Davidson LN, Fordham SV, Francis MP, Pollock CM, Simpfendorfer CA, Burgess GH, Carpenter KE, Compagno LJ, Ebert DA, Gibson C, Heupel MR, Livingstone SR, Sanciangco JC, Stevens JD, Valenti S, White WT (2014) Extinction risk and conservation of the world's sharks and rays. eLife 3: e00590

Dwyer RG, Krueck NC, Udyawer V, Heupel MR, Chapman D, Pratt HL, Garla R, Simpfendorfer, CA (2020) Individual and population benefits of marine reserves for reef sharks. Curr. Biol. 30 (3): 480-489 doi.org/10.1016/j.cub.2019.12.005.

Edwards S (2018) WWF statement on MSC certification of Spanish Purse Seine "Echebastar" Fishery in the Indian Ocean. wwf.panda.org/wwf_news/press_releases/?337217/WWF-Statementon-MSC-certification-of-Spanish-Purse-Seine-Echebastar-Fishery-in-the-Indian-Ocean\%C2\%A0

Environmental Protection Agency, USA (US EPA) (2000) Guidance for Assessing Chemical Contaminant Data for Use in Fish Advisories, Volume 2: Risk Assessment and Fish Consumption Limits. 3rd ed. U.S. Environmental Protection Agency, Office of Science and Technology, Office of Water, Washington, D.C. EPA-823-B-00-008.

www.epa.gov/waterscience/fish/advice/volume2/index.html (accessed 14 April 2020) 
Erickson DL, Berkeley SA (2008) Methods to reduce bycatch mortality in longline fisheries. In: Sharks of the open ocean: biology, fisheries and conservation. Ed: Camhi MD, Pikitch EK, Babcock EA. Blackwell Publishing, Oxford, UK pp. 462-471.

European Union Plenary sitting (2020) Recommendation on the draft Council decision on the conclusion, on behalf of the European Union, of the Protocol to amend the International Convention for the Conservation of Atlantic Tunas (13447/2019 - C9-0187/2019 - 2019/0225(NLE)) 27.4.2020 www.europarl.europa.eu/doceo/document/A-9-2020-0089_EN.pdf (accessed 07 August 2020)

EU Monitor (2022) Explanatory Memorandum to COM(2002)185 - Conservation and sustainable exploitation of fisheries resources under the Common Fisheries Policy www.eumonitor.eu/9353000/1/j4nvhdfdk3hydzq_j9vvik7m1c3gyxp/vi8rm2yv7ezh (accessed 5 January 2022)

Ewell C, Hocevar J, Mitchell E, Snowden S, Jacquet J (2020) An evaluation of Regional Fisheries Management Organization at-sea compliance monitoring and observer programs Mar. Pol. 115:103842 doi.org/ 10.1016/j.marpol.2020.103842

FAO (2020) The State of World Fisheries and Aquaculture 2020. Sustainability in action. Rome. doi.org/10.4060/ca9229en

Ferretti F, Myers RA, Serena F, Lotze HK (2008) Loss of large predatory sharks from the Mediterranean Sea. Conserv. Biol. 22, 952-964.

Ferretti F, Worm B, Britten GL, Heithaus MR, Lotze HK (2010) Patterns and ecosystem consequences of shark declines in the ocean. Ecol. Lett. 13(8):1055-1071 doi.org/0.1111/j.14610248.2010.01489.x

Ferretti F, Jacoby DMP, Pfleger MO, White TD, Dent F, Micheli F, Rosenberg AA, Crowder, LB, Block, BA (2020) Shark fin trade bans and sustainable shark fisheries. Conserv. Lett. e12708. doi.org/10.1111/conl.12708

Fields AT, Fischer GA, Shea, SKH, Zhang H, Abercrombie DL, Feldheim KA, Babcock EA, Chapman DD (2017) Species composition of the international shark fin trade assessed through a retail-market survey in Hong Kong, Conserv. Biol. 1523-1739

Filmalter JD, Capello M, Deneubourg J, Cowley PD, Dagorn L (2013) Looking behind the curtain: quantifying massive shark mortality in fish aggregating devices. Front. Ecol. Environ. 11: 291-296. doi.org/10.1890/130045

Fischer J, Erikstein K, D'Offay B, Guggisberg S, Barone M (2012) Review of the Implementation of the International Plan of Action for the Conservation and Management of Sharks FAO Fisheries and Aquaculture Circular. No. 1076 2012, p.65 www.fao.org/3/i3036e/i3036e00.htm (accessed 12 August 2020) 
Fisheries and Oceans Canada (2020) North Atlantic Shortfin Mako Management 2020-2021 ecologyaction.ca/sites/default/files/images-documents/shortfin\%20mako.pdf (accessed 12 August 2020)

Florida Department of Health (2019) Florida Advisory on Fish Consumption. www.floridahealth.gov/programs-and-services/prevention/healthy-weight/nutrition/seafoodconsumption/_documents/fish-advisory-big-book2019.pdf (accessed 17 April 2020)

Florida Fish and Wildlife Conservation Commission. myfwc.com/fishing/saltwater/recreational/sharks/ (accessed 14 April 2020)

Fordham S, Fowler SL, Coelho RP, Goldman K, Francis MP (2016) The IUCN Red List of Threatened Species: Squalus acanthias. doi.org/10.2305/IUCN.UK.20161.RLTS.T91209505A2898271.en (accessed 14 April 2020)

Freire KD, Christensen V, Pauly D (2008) Description of the East Brazil Large Marine Ecosystem using a trophic model. Biol. Corpus ID: 3911634 doi.org/10.3989/scimar.2008.72n3477

Friedlander A, Beets J, Tobias W (1994) Effects of Fish Aggregating Device Design and Location on Fishing Success in the U.S. Virgin Islands. Bull. Mar. Sci. 55(2-3):592-601

Friedrich LA, Jefferson R, Glegg G (2014) Public perceptions of sharks: Gathering support for shark conservation Mar. Pol. 47:1-7 doi.org/10.1016/j.marpol.2014.02.003

Froese R, Zeller D, Kleisner K, Pauly D (2012) What catch data can tell us about the status of global fisheries. Mar Biol 159:1283-1292 doi.org/10.1007/s00227-012-1909-6

Gehan SM (2019) Testimony of the Sustainable Shark Alliance Before the House Subcommittee on Water, Oceans, and Wildlife March 26, 2019 naturalresources.house.gov/imo/media/doc/Gehan\%20Testimony\%20WOW\%20Leg\%20Hrg\%200 3.26.19.pdf (accessed 14 April 2020)

Goldfarb B (2016) Cod Is Dead-Is Dogfish the Answer? Boston Newsmagazine. www.bostonmagazine.com/restaurants/2016/08/14/dogfish (accessed 17 April 2020)

Greenpeace (2020) Choppy Waters: Forced Labour and Illegal Fishing in Taiwan’s Distant Water Fisheries www.greenpeace.org/southeastasia/publication/3690/choppy-waters-forced-labour-andillegal-fishing-in-taiwans-distant-water-fisheries/ (accessed 12 August 2020)

Guinot G, Cavin L (2016) 'Fish' (Actinopterygii and Elasmobranchii) diversification patterns through deep time. Biol. Rev. 91:950-981.

Guida L (2021) Why we should \#GiveFlakeABreak Australian Marine Conservation Society www.marineconservation.org.au/wp-content/uploads/2021/01/210120_Flake-Report-Full-

Report.pdf (accessed 18 April 2021) 
Hammerschlag N, Williams L, Fallows M, Fallows C. (2019) Disappearance of white sharks leads to the novel emergence of an allopatric apex predator, the sevengill shark. Sci Rep 9, 1908 (2019). https://doi.org/10.1038/s41598-018-37576-6

Hanich Q, Davis R, Holmes G, Amidjogbe ER, Campbell B (2019) Drifting Fish Aggregating Devices (FADs) Deploying, Soaking and Setting - When Is a FAD 'Fishing'? Int. J. Mar. Coast. 124. doi.org/10.1163/15718085-23441103

Hareide NR, Carlson J, Clarke M, Clarke S, Ellis J, Fordham S, Fowler S, Pinho M, Raymakers C, Serena F, Seret B, Polti S (2008) European shark fisheries: a preliminary investigation into fisheries, conversion factors, trade products, markets and management measures. European Elasmobranch Association. IOTC-2008-WPEB-INF04 www.iotc.org/documents/european-sharkfisheries-preliminary-investigation-fisheries-conversion-factors-trade (accessed 10 March 2021

Harrington JM, Myers RA, Rosenberg AA (2005) Wasted fishery resources: discarded bycatch in the USA. FishFish. 6:350-61

Heithaus MR, Frid A, Wirsing AJ, Dill LM, Fourqurean JW, Burkholder D, Thomson J, Bejder, L (2007) State-dependent risk-taking by green sea turtles mediates top-down effects of tiger shark intimidation in a marine ecosystem. J Anim Ecol6:837-844 doi.org/10.1111/j.13652656.2007.01260.x

Heithaus MR, Frid A, Wirsing AJ, Worm B (2008) Predicting ecological consequences of marine top predator declines. Trends Ecol. Evol.. 23(4):202-210.

Hesser A (2006) The Way We Eat: Market Value. The New York Times Magazine June 12006 https://www.nytimes.com/2006/06/11/magazine/the-way-we-eat-market-value.html

Hobbs CAD, Potts RWA, Bjerregaard WM, Usher J, Griffiths AM (2019) Using DNA Barcoding to Investigate Patterns of Species Utilisation in UK Shark Products Reveals Threatened Species on Sale. Sci Rep 9, 1028. doi.org/10.1038/s41598-018-38270-3

Human Rights at Sea (2020) Fisheries Observer Deaths at Sea, Human Rights and the Role and Responsibilities of Fisheries Organisations www.humanrightsatsea.org/2020/07/03/report-fisheriesobserver-deaths-at-sea-human-rights-and-the-role-and-responsibilities-of-fisheries-organisations/ (accessed 3 March 2021

Hutchinson MR, Itano D, Muir JA, Holland KN (2015) Post-release survival of juvenile silky sharks in the tropical tuna purse seine fishery. Mar. Ecol. Prog. Ser, 521: 143- 154.

ICCAT (2017)a Report of the Standing Committee on Research and Statistics (SCRS) (Madrid, Spain, 2 to 6 October 2017) www.iccat.int/Documents/Meetings/Docs/2017_SCRS_REP_ENG.pdf (accessed 12 January 2022) 
ICCAT (2017)b Recommendation by ICCAT on the conservation of North Atlantic stock of shortfin mako of shortfin mako caught in association with ICCAT fisheries. Rec. 17-08 www.iccat.int/Documents/Recs/compendiopdf-e/2017-08-e.pdf (accessed 12 January 2022)

ICCAT (2019) International Commission for the Conservation of Atlantic Tunas Report of the Standing Committee on Research and Statistics (SCRS) Madrid, Spain, 30 September to 4 October 2019 www.iccat.int/Documents/Meetings/Docs/2019/REPORTS/2019_SCRS_ENG.pdf (accessed 22 April 2020)

ICCAT (2020) Summary Report by the Commission Chair 2020 COM Doc. No. PLE_150_A / 2020 February 2, 2021 (12:22 PM) www.iccat.int/com2020/ENG/PLE_150A_ENG. pdf (Accessed 9 March 2021)

ICCAT (2021)a Report of the Standing committee on Research and Statistics. (SCRS) (Online, 27 September to 2 October 2021)

www.iccat.int/Documents/Meetings/Docs/2021/REPORTS/2021_SCRS_ENG.pdf (accessed 4 December 2021)

ICCAT (2021)b ICCAT Press Release ICCAT agreed a new conservation measure for the North Atlantic shortfin mako shark. Closure of the 27th Regular meeting of the Commission 23 November 2021

www.iccat.int/Documents/Meetings/COMM2021/PRESS_RELEASE_ENG.pdf（accessed 4 December 2021)

India: Humane Society International/India (2013) 'Fins Naturally Attached' Policy Adopted to Protect Sharks www.hsi.org/news-media/fins_attached_india_082613/ (accessed 5 January 2022)

IOTC (2020) Report of the 23rd Session of the IOTC Scientific Committee, IOTC-2020-SC23$\mathrm{R}[\mathrm{E}]$; Held by video-conference, 7 - 11 December 2020

www.iotc.org/sites/default/files/documents/2021/01/IOTC-2020-SC23-RE.pdf (accessed 14 May 2021)

IPBES (2019) Global assessment report on biodiversity and ecosystem services of the Intergovernmental Science-Policy Platform on Biodiversity and Ecosystem Services. E. S. IPBES secretariat, Bonn, Germany.

IUCN Red List www.iucnredlist.org (accessed 24 April 2020)

Jones JB (1992) Environmental impact of trawling on the seabed: a review. N. Z. J. Mar. 26(1):5967 doi.org/10.1080/00288330.1992.9516500

Kaplan IC, Cox SP, Kitchell JF (2007) Circle hooks for Pacific longliners: not a panacea for marlin and shark bycatch, but part of the solution. Trans. Am. Fish. Soc. 136:392-401. doi:10.1577/T05301.1 . 
Kao E (2017) Hong Kong shark fin traders 'will be hit hard' by proposal to protect blue sharks. South China Morning Post. www.scmp.com/news/hong-kong/healthenvironment/article/2108502/hong-kong-shark-fin-traders-will-be-hit-hard (accessed 14 April 2020)

Kearns M (2015) IPNLF: Tuna fishery certification 'fatally flawed.' Seafood Source www.seafoodsource.com/news/environment-sustainability/ipnlf-tuna-fishery-certification-fatallyflawed (accessed 24 April 2020)

Kowacki EB (2018) Can dogfish save Cape Cod Fisheries? Christian Science Monitor www.csmonitor.com/Environment/2018/0820/Can-dogfish-save-Cape-Cod-fisheries (accessed 27 April 2020)

Kriwet J, Benton MJ (2004) Neoselachian (chondrichthyes, Elasmobranchii) diversity across the cretaceous-tertiary boundary. Palaeogeogr. Palaeoclimatol. Palaeoecol. 214:181-194

Kriwet J, Kiessling W, Klug S (2009) Diversification trajectories and evolutionary life-history traits in early sharks and batoids. Proc. R. Soc. B 276 945-951

Lam VYY, Sadovy de Mitcheson Y (2011) The sharks of South East Asia - unknown, unmonitored and unmanaged. Fish Fish 12:51-74. doi.org/10.1111/j.1467-2979.2010.00383.x

Lorenz K (1963) Das Sogenannte Böse, Zur Naturgeschichte der Aggression. Verlag Dr BorothaSchoeler, Vienna, Austria

MacNeil MA, Chapman DD, Heupel M. et al. (2020) Global status and conservation potential of reef sharks. Nature. doi.org/10.1038/s41586-020-2519-y

MSA: Magnuson-Stevens Fishery Conservation and Management Act (1976) 16 U.S.C. §§18011891d. https://uscode.house.gov/view.xhtml?path=/prelim@title16/chapter38\&edition=prelim (accessed 5 January 2022)

Maine Seafood Guide, University of Maine. seagrant.umaine.edu/maine-seafood-guide (accessed 14 April 2020)

Marine Stewardship Council (2018) Critical requirements necessary to improve marine stewardship council principle awionline.org/sites/default/files/uploads/documents/temp/AWI-ML-Open-Letterto-MSC-012018.pdf (accessed 12 August 2020)

Marine Stewardship Council (2020) US spiny dogfish and winter skate. fisheries.msc.org/en/fisheries/us-atlantic-spiny-dogfish-and-winter-skate/ (accessed 24 April 2020)

Marine Stewardship Council (2020) Echebastar Indian Ocean purse seine skipjack tuna. fisheries.msc.org/en/fisheries/echebastar-indian-ocean-purse-seine-skipjack-tuna (accessed 10 March 2021) 
Mason F (2002) The Newfoundland Cod Stock Collapse: A Review and Analysis of Social Factors. Electron. Green J. UCLA escholarship.org/uc/item/19p7z78s

McVeighand K, Firdaus F (2020) 'Hold on Brother': final days of doomed crew on Chinese shark finning boat. The Guardian 7 July 2020 www.theguardian.com/environment/2020/jul/07/hold-onbrother-final-days-of-doomed-crew-on-chinese-shark-finning-boat (accessed 12 August 2020)

Meadows DH, Meadows DL, Randers J, Behrens WW. (1972) The Limits to Growth. Universe Books, New York.

Meere F, Lack M (2008) Assessment of Impacts of Illegal, Unreported and Unregulated (IUU) Fishing in the Asia-Pacific Asia-Pacific Economic Cooperation Fisheries Working Group APEC\#208-FS-01.5

Mourier J, Vercelloni J, Planes S (2012) Evidence of social communities in a spatially structured network of a free-ranging shark species. Anim. Beh., 83(2): 389-401.

Rutger H (2018) Sustainable shark trade bill offers science based solutions for overfishing. Mote Laboratories mote.org/news/article/sustainable-shark-trade-bill-offers-science-based-solutions-foroverfishing (aAccessed 10 January 2022)

Mumby PJ, Dahlgren CP, Harborne AR, Kappel CV, Micheli F, Brumbaugh DR, Holmes KE, Mendes JM, Broad K, Sanchirico JN, Buch K, Box S, Stoffle RW, Andrew B. Gill AB. Fishing, Trophic Cascades, and the Process of Grazing on Coral Reefs. Science: 98-101. science.sciencemag.org/content/311/5757/98 /doi/10.1126/science.1121129 $\quad$ (accessed 20 December 2021)

Musick JA, Musick S (2011) Sharks. FAO Fisheries and Aquaculture Reviews and Studies. Rome, FAO 13p.

Myers RA, Worm B (2003) Rapid worldwide depletion of predatory fish communities. Nature. 423(6937):280-3. doi.org/10.1038/nature01610

Myers RA, Baum JK, Shepherd TD, Powers SP, Peterson CH (2007) Cascading effects of the loss of apex predatory sharks from a coastal ocean. Science 423(6937): 280-3 doi.org/10.1126/science.1138657

Nadon MO, Baum JK, Williams ID, McPherson JM, Zgliczynski BJ, Richards BL, Schroeder RE, Brainard RE. (2012) Re-creating missing population baselines for Pacific reef sharks. Conserv Biol. 2012 Jun;26(3):493-503. doi: 10.1111/j.1523-1739.2012.01835.x. Epub 2012 Apr 26. PMID: 22536842 ; PMCID: PMC3494310.

New York Post (2016) Fish sticks for millennials! Seafood industry rebrands 'trash fish'. nypost.com/2016/01/21/the-new-fish-sticks-for-millennials (accessed 22 April 2020) 
NOAA Fisheries (2016) Shark Finning Report to Congress. repository.library.noaa.gov/view/noaa/17060 (accessed 14 April 2020)

NOAA Fisheries (2020) Atlantic Spiny Dogfish. www.fisheries.noaa.gov/species/atlantic-spinydogfish: Accessed 6 May 2020

Norse EA, Brooke S, Cheung WWL, Clark MR, Ekeland I, Froese R, Gjerde KM, Haedrich RL, Heppell SS, Morato T, Morgan LE, Pauly D, Sumaila R, Watson, R (2011) Sustainability of deepsea fisheries. Mar. Pol. 36(2)307-320 doi.org/10.1016/j.marpol.2011.06.008

OED Online: Oxford English Dictionary, Oxford University Press, Oxford. www.oed.com (accessed 2021-12-28)

O’Leary BC, Winther-Janson M, Bainbridge JM, Aitken J, Hawkins JP, Roberts CM (2016) Effective Coverage Targets for Ocean Protection. Conserv. Lett. 9: 398-404 doi.org/10.1111/conl.12247

Okes N, Sant G (2019) An overview of major shark traders, catchers and species. TRAFFIC, Cambridge, UK.

Okey TA, Banks S, Born AF, Bustamante RH, Calvopiña M, Edgar GJ, Espinoza E José MiguelFariña J, Garske LE, Reck GK Salazar S, Shepherd S, Toral-Granda V, Wallem P (2004) A trophic model of a Galápagos subtidal rocky reef for evaluating fisheries and conservation strategies. Ecol. Model.172:383-401

Oliver S, Braccini M, Newman SJ, Harvey ES (2015) Global patterns in the bycatch of sharks and rays. Mar. Pol. 54:86-97. doi.org/ 10.1016/j.marpol.2014.12.017

Pacoureau N, Rigby CL, Kyne PM, Sherley RB, Winker H, Carlson JK, Fordham SV, Barreto R, Fernando D, Francis MP, Jabado RW, Herman KB, Liu KM, Marshall AD, Pollom RA, Romanov EV, Simpfendorfer CA, Yin JS, Kindsvater HK, Dulvy NK (2021) Half a century of global decline in oceanic sharks and rays. Nature 589: 567-571 doi.org/10.1038/s41586-020-03173-9

PADI (2011) www.diveagainstdebris.org/action/shark-awareness-campaign (accessed 2022-01-08)

Papastamatiou YP, Bodey TW, Caselle JE, Bradley D, Freeman R, Friedlander AM. Jacoby DMP (2020) Multiyear social stability and social information use in reef sharks with diel fission-fusion dynamics Proc. R. Soc. B.28720201063 doi.org/10.1098/rspb.2020.1063

Pauly D, Zeller D (2016) Catch reconstructions reveal that global marine fisheries catches are higher than reported and declining. Nat. Commun 710244 doi.org/10.1038/ncomms10244

Poisson F, Filmalter JD, Vernet AL, Dagorn L (2014) Mortality rate of silky sharks (Carcharhinus falciformis) caught in the tropical tuna purse seine fishery in the Indian Ocean. Can. J. Fish. Aquat. Sci. 71, 1-4. 
Porcher IF (2010) The Shark Sessions: My Sunset Rendezvous. Strategic Book Publishing, Traverse City, Michigan, USA

Porcher IF (2017) The True Nature of Sharks. Independent. USA

Porcher IF, Darvell BW, Cuny G (2019) Response to “A United States shark fin ban would undermine sustainable shark fisheries” D.S. Shiffman \& R.E. Hueter, Mar. Pol. 85 (2017) 138-140. Marine Policy. 104:85-89 doi.org/10.1016/j.marpol.2019.02.058

Preikshot D, Pauly D (2005) Global Fisheries and Marine Conservation: Is Coexistence Possible? Chapter 11, pp. 185-197, in: Norse EA Crowder LB (2005) Marine Conservation Biology: the Science of Maintaining the Sea's Biodiversity Island Press, Washington, USA

Queiroz N, Humphries N, Couto A, Vedor M, da Costa I, Sequeira A, Mucientes G, Santos A, Abascal F, Abercrombie D, Abrantes K, Acuña-Marrero D, Afonso A, Afonso P, Anders D, Araujo G, Arauz R, Bach P, Barnett A, Sims D (2019) Global spatial risk assessment of sharks under the footprint of fisheries. Nature. 572. 1. 10.1038/s41586-019-1444-4.

Rago PJ, Sosebee KA, Brodziak JK, Murawski SA, Anderson ED (1998) Implications of recent increases in catches on the dynamics of Northwest Atlantic spiny dogfish (Squalus acanthias). doi.org/10.1016/S0165-7836(98)00181-7

Reid DG, Graham N, Suuronen P, He P, Pol M (2016) Implementing balanced harvesting: practical challenges and other implications. ICES J. Mar. Sci. 73:1690-1696. doi: 10.1093/icesjms/fsv253

Rigby CL, Barreto R, Carlson J, Fernando D, Fordham S, Francis MP, Jabado RW, Liu KM, Marshall A, Pacoureau N, Romanov E, Sherley RB, Winker H (2019) Isurus oxyrinchus The IUCN Red List of Threatened Species 2019: e.T39341A2903170. doi.org/10.2305/IUCN.UK.20191.RLTS.T39341A2903170.en

Rosello M, Vilata J, Belhabib D (2021) Atlantic Shortfin Mako: Chronicle of a Death Foretold? Laws 10(3): 52 . doi.org/10.3390/laws10030052

Sadovy de Mitcheson Y, Andersson AA, Hofford A, Law CSW, Hau LCY, Pauly D (2018) Out of control means off the menu: The case for ceasing consumption of luxury products from highly vulnerable species when international trade cannot be adequately controlled; shark fin as a case study. Mar. Pol. 98:115-120. doi.org/10.1016/j.marpol.2018.08.012

Sala E, Mayorga J, Costello C, Kroodsma D, Palomares MLD, Pauly D, Sumaila UR, Zeller D (2018) The economics of fishing the high seas. Sci. Adv 4(6) doi.org/10.1126/sciadv.aat2504

Sea Shepherd (2017a) Operation Sola Stella: Combatting Illegal Fishing in Liberia, West Africa seashepherd.org/campaigns/iuu-fishing-africa/iuu-campaigns/sola-stella/ (accessed 22 August 2020) 
Sea Shepherd (2017b) Arrest of poaching vessel shows shark liver oil production could drive species to extinction. www.seashepherdglobal.org/latest-news/shark-liver-oil-labiko2/ (accessed 4 June 2021)

Shiffman DS, Hueter RE (2017) A United States shark fin ban would undermine sustainable shark fisheries. Mar. Pol. 85:138-140.

Shiffman DS, Macdonald CC, Wallace SS, Dulvy NK (2021) The role and value of science in shark conservation advocacy Sci. Rep. 11:16626 doi.org/10.1038/s41598-021-960204www.nature.com/scientificreport

Simpfendorfer CA, Dulvy NK (2017) Bright spots of sustainable shark fishing. Curr. Biol. 27: R97-R98.

St. Gelais AT, Costa-Pierce BA (2016) Mercury concentrations in Northwest Atlantic wintercaught, male spiny dogfish (Squalus acanthias): A geographic mercury comparison and risk-reward framework for human consumption. Mar. Poll. Bull., 102(1):199-205. doi.org/10.1016/j.marpolbul.2015.12.009

Stelfox M, Bulling M, Sweet M (2019) Untangling the origin of ghost gear within the Maldivian archipelago and its impact on olive ridley (Lepidochelys olivacea) populations. Endang. Spec. Res. 40:309-320. doi.org/10.3354/esr00990

Stevens JD, Bonfil R, Dulvy NK, Walker PA (2000) The effects of fishing on sharks, rays, and chimaeras (chondrichthyans), and the implications for marine ecosystem. ICES J. Mar.Sci. 57: 476494.

Sumaila U, Rashid K, Ahmed TL, Watson R, Tyedmers P, Pauly D (2010) Subsidies to high seas bottom trawl fleets and the sustainability of deep-sea demersal fish stocks. Mar. Pol. 34(3):495-497 doi.org/10.1016/j.marpol.2009.10.004

Sumaila RU, Ebrahim N, Schuhbauer A, Skerritt D, Li Y, Sik Kim H, Mallory TG, Lam VWL, Pauly D (2019) Updated estimates and analysis of global fisheries subsidies. Mar. Pol. 109:103695 doi.org/10.1016/j.marpol.2019.103695.

Sumaila UR, Zeller D, Hood L, Palomares MLD, Li Y, Pauly D (2020) Illicit trade in marine fish catch and its effects on ecosystems and people worldwide. Sci. Adv. eaaz3801 doi.org/10.1126/sciadv.aaz3801

Taylor DL, Kutil NJ, Malek AJ, Collie JS (2014) Mercury bioaccumulation in cartilaginous fishes from southern new England coastal waters: contamination from a trophic ecology and human health perspective. Mar. Environ. Res. 99:20-33

Tsikliras AC, Froese R (2019) Maximum Sustainable Yield. in: Fath BD (ed) Encyclopedia of Ecology, 2nd ed., vol. 1:108-115. Oxford: Elsevier. 
Travis W (1961) Shark For Sale. Rand McNally Chicago

Travis J, Coleman FC, Auster PJ, Cury PM, Estes JA, Orensanz J, Peterson CH, Power ME, Steneck RS, Wootton TJ (2014) Species interactions and fisheries management. Proc. Natl. Acad. Sci. 111 (2) 581-584; doi.org/10.1073/pnas.1305853111

Vaness B (2019) Sustainable Shark Alliance: Setting the Record Straight on Sharks for Ocean Week www.accesswire.com/547715/Sustainable-Shark-Alliance-Setting-the-Record-Straight-onSharks-for-Ocean-Week (Aaccessed 10 January 2022)

Vedor M, Queiroz N, Mucientes G (2021) Climate-driven deoxygenation elevates fishing vulnerability for the ocean's widest ranging shark eLife 2021;10:e62508 doi.org/10.7554/eLife.62508

Villate-Moreno M, Pollerspöck J, Kremer-Obrock F, Straube N (2021) Molecular analyses of confiscated shark fins reveal shortcomings of CITES implementations in Germany.

Conserv. Sci. Pract.. 2021;e398. doi.org/10.1111/csp2.398

Vincent ACJ, Sadovy de Mitcheson Y, Fowler SL, Lieberman S (2013) The role of CITES in the conservation of marine fishes subject to international trade. Fish Fish. 15: 563-592.

Walker TI (1998) Can shark resources be harvested sustainability? A question revisited with a review of shark fisheries. Mar. Freshw. Res. 49:553-572.

Wang Y, Zhou C, Xu L, Wan R, Shi J, Wang X, Tang H, Wang L, Yu W, Wang K (2020) Degradability evaluation for natural material fibre used on fish aggregation devices (FADs) in tuna purse seine fishery, Aquaculture and Fisheries, doi.org/10.1016/j.aaf.2020.06.014.

Ward P, Myers RA (2005) Shifts in open-ocean fish communities coinciding with the commencement of commercial fishing. Ecol. 86:835-847.

Ward-Paige CA, Keith DM, Worm B, Lotze HK (2012) Recovery potential and conservation options for elasmobranchs. J. Fish. Biol. 80:1844-1869 doi.org/10.1111/j.1095-8649.2012.03246.x

Ward-Paige CA (2017) A global overview of shark sanctuary regulations and their impact on shark fisheries. Mar. Pol. 82:87-97 doi.org/10.1016/j.marpol.2017.05.004

Wegner NC. Lai NC, Bull KB, Graham JB (2012) Oxygen utilization and the branchial pressure gradient during ram ventilation of the shortfin mako, Isurus oxyrinchus: Is lamnid shark-tuna convergence constrained by elasmobranch gill morphology? J. Exp. Biol. 215: 22-28.

Widjaja S, Long T, Wirajuda H, Van As H, Bergh PE, Brett A, Copeland D, Fernandez M, Gusman A, Juwana S, Ruchimat T, Trent S, Wilcox C (2020) Illegal, Unreported and Unregulated Fishing and Associated Drivers. Washington, DC: World Resources Institute. www.oceanpanel.org/iuufishing-and-associated-drivers. (accessed 9 April 2021) 
Wiersma J, Carroll M (2018) An Economic Analysis of Spiny Dogfish: Historical Trends, Future Markets, and Implications for Management Action. Massachusetts Division of Marine Fisheries, Seafood Marketing Program. www.mass.gov/files/documents/2018/12/05/An Economic Analysis of Spiny Dogfish.pdf (accessed 14 April 2020)

Witkin T, Dissanayake ST, McClenachan L (2015) Opportunities and barriers for fisheries diversification: Consumer choice in New England, Fish. Res. 168:56-62.

World Bank (2017) The Sunken Billions Revisited: Progress and Challenges in Global Marine Fisheries. Environment and Sustainable Development series. doi.org/10.1596/978-1-4648-0919-4

Worm B, Davis B, Kettemer L, Ward-Paige CA, Chapman D, Heithaus MR, Kessel ST, Gruber SH (2013) Global catches, exploitation rates, and rebuilding options for sharks. Mar Pol 40:194-204 doi.org/10.1016/j.marpol.2012.12.034.

Ziegler I (2019) Shark Finning - a Case Study Highlighting the Lack of Best Practice and Application of a Risk Based Need for Data "Combating Shark Finning, an IUU fishing activity that severely undermines conservation efforts” Transparency and Monitoring to Combat IUU in MSC Certified Fisheries www.make-stewardship-count.org/wp-content/uploads/2020/01/Iris-ZieglerDiscussion-Paper-Shark-Finning.pdf (accessed 12 August 2020)

Ziegler AH, Millward S, Woodroffe K, Vail C, Guida L, Hofford A, Arauz R (2021) Analysis of the Marine Stewardship Council's policy on shark finning and the opportunity for adoption of a 'Fins Naturally Attached' policy in the MSC. Fisheries Standard Review www.sharkproject.org/wpcontent/uploads/2021/02/Analyis-of-the-Marine-Stewardship-Councils-policy-on-shark-finningFebruary-2021.pdf (accessed 4 June, 2021)

Zhou S, Kolding J, Garcia SM, Plank MJ, Bundy A, Charles A, Hansen A, Heino M, Howell D, Jacobsen NS, Reid DG, Rice JC, van Zwieten PAM (2019) Balanced harvest: concept, policies, evidence, and management implications. 